\title{
Methane and carbon dioxide emissions from 40 lakes along a north-south latitudinal transect in Alaska
}

\author{
A. Sepulveda-Jauregui ${ }^{1}$, K. M. Walter Anthony ${ }^{1}$, K. Martinez-Cruz ${ }^{1,2}$, S. Greene ${ }^{3}$, and F. Thalasso ${ }^{1,2}$ \\ ${ }^{1}$ Water and Environmental Research Center, University of Alaska Fairbanks, P.O. Box 5860, \\ 99775 Fairbanks, Alaska, USA \\ ${ }^{2}$ Biotechnology and Bioengineering Department, Cinvestav, 07360 Mexico City, D. F., Mexico \\ ${ }^{3}$ Department of Chemistry, The University of Chicago, 60637 Chicago, Illinois, USA
}

Correspondence to: K. M. Walter Anthony (kwalteranthony@alaska.edu)

Received: 20 July 2014 - Published in Biogeosciences Discuss.: 16 September 2014

Revised: 14 April 2015 - Accepted: 25 April 2015 - Published: 2 June 2015

\begin{abstract}
Uncertainties in the magnitude and seasonality of various gas emission modes, particularly among different lake types, limit our ability to estimate methane $\left(\mathrm{CH}_{4}\right)$ and carbon dioxide $\left(\mathrm{CO}_{2}\right)$ emissions from northern lakes. Here we assessed the relationship between $\mathrm{CH}_{4}$ and $\mathrm{CO}_{2}$ emission modes in 40 lakes along a latitudinal transect in Alaska to lakes' physicochemical properties and geographic characteristics, including permafrost soil type surrounding lakes. Emission modes included direct ebullition, diffusion, storage flux, and a newly identified ice-bubble storage (IBS) flux. We found that all lakes were net sources of atmospheric $\mathrm{CH}_{4}$ and $\mathrm{CO}_{2}$, but the climate warming impact of lake $\mathrm{CH}_{4}$ emissions was 2 times higher than that of $\mathrm{CO}_{2}$. Ebullition and diffusion were the dominant modes of $\mathrm{CH}_{4}$ and $\mathrm{CO}_{2}$ emissions, respectively. IBS, $\sim 10 \%$ of total annual $\mathrm{CH}_{4}$ emissions, is the release to the atmosphere of seasonally icetrapped bubbles when lake ice confining bubbles begins to melt in spring. IBS, which has not been explicitly accounted for in regional studies, increased the estimate of springtime emissions from our study lakes by $320 \%$. Geographically, $\mathrm{CH}_{4}$ emissions from stratified, mixotrophic interior Alaska thermokarst (thaw) lakes formed in icy, organic-rich yedoma permafrost soils were 6-fold higher than from non-yedoma lakes throughout the rest of Alaska. The relationship between $\mathrm{CO}_{2}$ emissions and geographic parameters was weak, suggesting high variability among sources and sinks that regulate $\mathrm{CO}_{2}$ emissions (e.g., catchment waters, $\mathrm{pH}$ equilibrium). Total $\mathrm{CH}_{4}$ emission was correlated with concentrations of soluble reactive phosphorus and total nitrogen in lake water, Secchi depth, and lake area, with yedoma lakes having
\end{abstract}

higher nutrient concentrations, shallower Secchi depth, and smaller lake areas. Our findings suggest that permafrost type plays important roles in determining $\mathrm{CH}_{4}$ emissions from lakes by both supplying organic matter to methanogenesis directly from thawing permafrost and by enhancing nutrient availability to primary production, which can also fuel decomposition and methanogenesis.

\section{Introduction}

Lakes are an important source of atmospheric greenhouse gases, methane $\left(\mathrm{CH}_{4}\right)$, and carbon dioxide $\left(\mathrm{CO}_{2}\right)$ (Battin et al., 2009; Tranvik et al., 2009; Bastviken et al., 2011). In lakes, $\mathrm{CH}_{4}$ is produced, consumed, and exchanged with the atmosphere in a different manner than $\mathrm{CO}_{2} \cdot \mathrm{CH}_{4}$ is produced in anaerobic environments (mainly in sediments), while $\mathrm{CO}_{2}$ in lakes originates from respiration throughout the water column and sediments, inflow of terrestrially derived dissolved inorganic carbon from surrounding watersheds, and photooxidation of dissolved organic carbon (DOC) (Graneli et al., 1996; Tranvik et al., 2009; Weyhenmeyer et al., 2012; Maberly et al., 2013). $\mathrm{CO}_{2}$ is also formed in lakes by aerobic oxidation of $\mathrm{CH}_{4}$, a process that can consume a significant fraction of $\mathrm{CH}_{4}$ produced in lakes (Kankaala et al., 2006; Bastviken et al., 2008; Lofton et al., 2013). The ratio of $\mathrm{CO}_{2}$ emissions versus carbon sequestration in northern lakes was found to be controlled by nitrate concentrations in lake water (Kortelainen et al., 2013). Meanwhile, $\mathrm{CO}_{2}$ is consumed by photosynthesis and other autotrophic or chemical processes 
(e.g., increasing alkalinity, photooxidation) that depend on $\mathrm{pH}$ and/or the availability of light (Madigan et al., 2009).

Despite recycling of $\mathrm{CH}_{4}$ and $\mathrm{CO}_{2}$ internally in lakes, a significant quantity of these greenhouse gases is released from lakes to the atmosphere (Cole et al., 2007). Most of Earth's lakes are located in northern high latitudes, overlapping the permafrost-dominated region (Downing et al., 2006; Smith et al., 2007; Grosse et al., 2013). It is estimated that $\mathrm{CH}_{4}$ emission from lakes globally comprises about $16 \%$ (71.6 Tg) of all human and natural atmospheric sources, and that northern lakes $\left(>55^{\circ} \mathrm{N}\right)$ contribute about $20 \%$ of these emissions (13.6 Tg; Bastviken et al., 2011). In contrast, $\mathrm{CO}_{2}$ emissions from northern lakes constitute approximately $43 \%$ (1.2 $\mathrm{Pg} \mathrm{CO}_{2}$ ) of global emissions from lakes (Battin et al., 2009; Tranvik et al., 2009; Maberly et al., 2013). This disproportionality between the contribution of $\mathrm{CH}_{4}$ and $\mathrm{CO}_{2}$ emissions from northern lakes is not well understood, and may be due to numerous factors, including sensitivity of methanogenesis to temperature and lake trophic status (Tranvik et al., 2009; Ortiz-Llorente and Alvarez-Cobelas, 2012; Marotta et al., 2014) versus processes that control $\mathrm{CO}_{2}$ availability (e.g., photosynthesis, inputs from terrestrial ecosystems, and organic matter mineralization) (Kling et al., 1991; Battin et al., 2009; Tranvik et al., 2009). Furthermore, lake $\mathrm{CH}_{4}$ emission data are scarce relative to $\mathrm{CO}_{2}$ data, particularly at high northern latitudes (Tranvik et al., 2009; Bastviken et al., 2011). Due to a disproportionately low number of northern high-latitude lakes represented in previous studies of global $\mathrm{CH}_{4}$ emissions (Bastviken et al., 2011), and a paucity of studies that considered various modes of emission together, $\mathrm{CH}_{4}$ and $\mathrm{CO}_{2}$ emissions from northern high-latitude lakes are still poorly constrained.

Landscape diversity in Alaska provides a valuable opportunity to study $\mathrm{CH}_{4}$ and $\mathrm{CO}_{2}$ emission patterns from lakes as they relate to origin, climate, ecology, geology, and permafrost coverage. Across Arctic, continental, and transitional climate zones in Alaska, ecological habitats include Arctic, alpine, and forest tundra, and northern and southern boreal forests (Gregory-Eaves et al., 2000). The surficial geology in which Alaskan lakes are found varies primarily from fine-grain aeolian deposits; to coarser-grain coastal, glacial, fluvial, and volcanic deposits; to rubble and bedrock (Karlstrom et al., 1964; Arp and Jones, 2009). Alaska is also characterized by a variety of permafrost types (Fig. 1) ranging from isolated permafrost in south-central Alaska to continuous permafrost in northern Alaska (Jorgenson et al., 2008).

Within the context of permafrost soil organic carbon content, Alaskan lakes can be classified depending on whether they are surrounded by yedoma-type permafrost or nonyedoma substrates (Walter Anthony et al., 2012). Yedoma is typically thick (tens of meters), Pleistocene-aged loessdominated permafrost sediment with high organic carbon ( $\sim 2 \%$ by mass) and ice (50-90\% by volume) contents ( $\mathrm{Zi}$ mov et al., 2006). When yedoma thaws and ground ice melts, deep thermokarst (thaw) lakes with high $\mathrm{CH}_{4}$ production po-

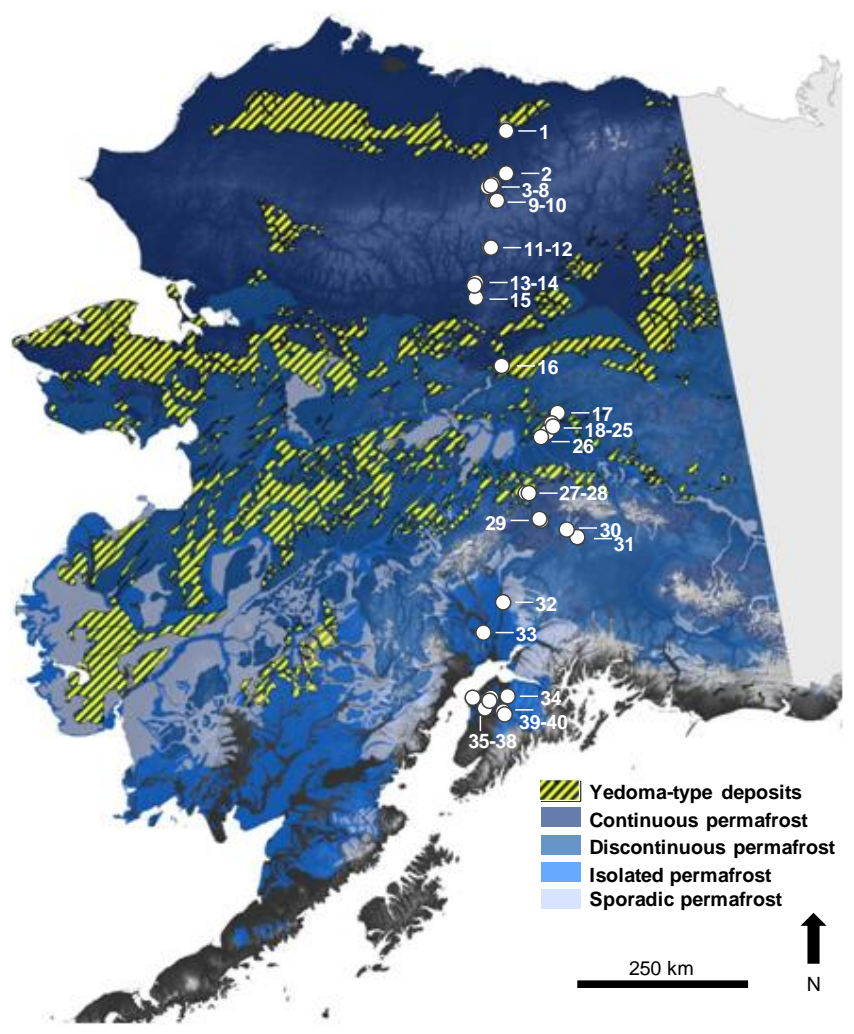

Figure 1. Locations of study lakes in Alaska (circles) plotted on the Alaska DEM hillshade raster. Information about the distribution of yedoma-type deposits (ice-rich silt containing deep thermokarst lakes) and permafrost is from Jorgenson et al. (2008) and Kanevskiy et al. (2011). The Alaska map is the National Elevation Dataset $30 \mathrm{~m}$ hillshade raster.

tentials form (Zimov et al., 1997; Kanevskiy et al., 2011; Walter Anthony and Anthony, 2013). Some non-yedoma permafrost soils can also have high organic carbon and excess ice concentrations within several meters of the ground surface; however, these organic- and ice-rich permafrost horizons are typically thinner than yedoma deposits (Ping et al., 2008; Tarnocai et al., 2009). As a result, thermokarst lakes formed in non-yedoma permafrost soils are commonly shallower than yedoma lakes and have been shown to emit less $\mathrm{CH}_{4}$ (West and Plug, 2008; Grosse et al., 2013; Walter Anthony and Anthony, 2013).

Estimating $\mathrm{CH}_{4}$ and $\mathrm{CO}_{2}$ emissions from northern highlatitude lakes, which are seasonally covered by ice, represents a difficult task because there are at least four emission pathways, all of which have not been consistently and simultaneously measured in the past: (1) direct ebullition, (2) diffusion, (3) storage flux, and a newly identified (4) ice-bubble storage (IBS) flux (Greene et al., 2014).

Ebullition (bubbling) has been observed as the dominant pathway of $\mathrm{CH}_{4}$ emissions from many lakes (Casper et al., 2000; Bastviken et al., 2004; Walter et al., 2006). Since $\mathrm{CH}_{4}$ is less soluble, high concentrations in interstitial sediment 
water lead to bubble formation and their emission to the atmosphere. In contrast, $\mathrm{CH}_{4}$ diffusion flux to the atmosphere is usually relatively low and occurs mainly in summer, when ice cover is absent. Due to much higher solubility, $\mathrm{CO}_{2}$ tends to occur in low concentrations in ebullition bubbles, and instead escapes lakes predominately by diffusion (Abril et al., 2005).

During winter, ice formation on most northern lakes impedes gas emissions to the atmosphere. Dissolved $\mathrm{CH}_{4}$ and $\mathrm{CO}_{2}$ accumulate in the lake water column beneath the ice, resulting in gas "storage". Storage emissions occur when dissolved $\mathrm{CH}_{4}$ and $\mathrm{CO}_{2}$ are emitted by diffusion when the ice melts in spring, often enhanced by full or partial lake overturn (Michmerhuizen et al., 1996; Phelps et al., 1998; Bellido et al., 2009). Storage emissions also occur in some lakes in fall if lake overturn caused by falling temperature brings high concentrations of dissolved gases from the hypolimnion to the surface, resulting in rapid $\mathrm{CH}_{4}$ and $\mathrm{CO}_{2}$ emission by diffusion from the water column. Bastviken et al. (2004) coined the term "storage flux" when they considered it in regional lake emission estimates as a function of differences in water column $\mathrm{CH}_{4}$ stocks before and after lake ice-out, $\mathrm{CH}_{4}$ production, and $\mathrm{CH}_{4}$ oxidation.

The fourth potential emission component involves $\mathrm{CH}_{4}$ release to the atmosphere from seasonally ice-trapped ebullition bubbles in spring before the ice disappears. During winter, emission to the atmosphere of many bubbles rising from sediments is impeded by seasonal lake ice. When bubbles come to rest under the ice, they exchange gases with the water column (Greene et al., 2014). Some bubbles become sealed in ice as ice thickens downward. Due to the insulation property of gas bubbles, ice is locally thinner where bubbles are trapped, and bubbles usually stack in vertical columns separated by ice lenses of various thicknesses. As a result, when lake ice begins to melt in spring, bubble-rich patches of ice begin to locally degrade before the rest of the ice sheet. These ebullition bubbles previously sealed in and under ice are released to the atmosphere by an emission mode termed "ice-bubble storage" (IBS) (Greene et al., 2014). Ponded water on the lake-ice surface can accelerate the release of icetrapped bubbles to the atmosphere and also provides the opportunity for visual observation of gas release from bubbles trapped by degrading ice (K. M. Walter Anthony, unpublished data, 2014). It should be noted that gas in small, tubular bubbles formed in lake ice by the exclusion of dissolved gases as ice freezes (Gow and Langston, 1977; Langer et al., 2015 ) is presumably released to the atmosphere when ice degrades as well; however, given the substantially lower concentration of $\mathrm{CH}_{4}$ in these non-ebullition, freeze-out bubbles (usually $<0.01 \%$ by volume; Boereboom et al., 2012), this mode of emission is relatively insignificant in comparison to the larger ebullition-sourced bubbles, in which $\mathrm{CH}_{4}$ concentrations typically range from 40 to $90 \%$ by volume (Martens et al., 1992; Semiletov et al., 1996; Walter Anthony et al., 2010).
Finally, it is important to understand how changes in nutrient availability and temperature influence $\mathrm{CO}_{2}$ and $\mathrm{CH}_{4}$ cycling in lakes. Increasing nutrients and temperature stimulates primary production and microbial decomposition of organic matter, which in turn consumes oxygen $\left(\mathrm{O}_{2}\right)$ and enhances anaerobic decay processes, particularly in sediments, where $\mathrm{CH}_{4}$ and $\mathrm{CO}_{2}$ are produced (Conrad et al., 2010). Aerobic $\mathrm{CH}_{4}$ oxidation is controlled directly by $\mathrm{O}_{2}$ and $\mathrm{CH}_{4}$ concentrations and temperature (Utsumi et al., 1998; Bastviken et al., 2002; Borrel et al., 2011) and indirectly by nutrient availability (Dzyuban et al., 2010). Measurements of $\mathrm{O}_{2}$ and $\mathrm{CH}_{4}$ concentrations in lakes are essential for assessing global carbon cycling, and in this framework, correlating both parameters in situ has been promoted as an indirect means of assessing $\mathrm{CH}_{4}$ oxidation by methanotrophs (Bastviken et al., 2004; Guerin and Abril, 2007; SepulvedaJauregui et al., 2012).

In this study we assessed the relationships between measured $\mathrm{CH}_{4}$ and $\mathrm{CO}_{2}$ emission modes in 40 lakes along a north-south Alaska transect to the lakes' physicochemical properties and geographic characteristics. Our goal was to assess the magnitude, variability, and seasonality of individual modes of emission, particularly among the wide range of geographic lake settings in Alaska.

\section{Materials and methods}

\subsection{Study lakes and permafrost zones}

We sampled water from 40 Alaskan lakes during open-water conditions in June-July 2011 and 2012 (Fig. 1) and from 26 of the lakes toward the end of the winter ice-cover period in March-April 2011. Measurements were usually made during daylight hours between 10:00 and 18:00 LT. Our study lakes were located near the road system along a north-south transect in Alaska that spans a variety of geographic and limnological settings, described previously by Gregory-Eaves et al. (2000), Jorgenson et al. (2008), and Walter Anthony et al. (2012). Our study lakes occupied three general climatic/permafrost zones: (1) the northern study area (66$70^{\circ} \mathrm{N}$, Arctic climate/continuous permafrost), (2) the interior study area $\left(64-66^{\circ} \mathrm{N}\right.$, continental climate/discontinuous permafrost), and the southern study area $\left(60-64^{\circ} \mathrm{N}\right.$, transitional climate/sporadic and isolated permafrost) (Gregory-Eaves et al., 2000; Jorgenson et al., 2008). Additionally, we distinguished yedoma-type thermokarst lakes as those formed in yedoma permafrost with active, ongoing thermokarst activity from non-yedoma-type lakes, which were lakes occurring in other non-yedoma deposits in permafrost and nonpermafrost soils (Fig. 1). Lake names, sizes, geographic characteristics, and limnological properties are shown in Table 1. 
Table 1. Lake physical and chemical properties from 40 Alaskan lakes. $N$ - lake number; * indicates informal lake names, and the A number refers to lake identification numbers used by Gregory Eaves et al. (2000) for study of the same lakes; Y/NY ${ }^{\mathrm{a}, \mathrm{b}}$ - permafrost soil type as yedoma or non-yedoma; $\mathrm{TSI}^{\mathrm{c}}$ - trophic state index; $\mathrm{EC}^{\mathrm{d}}$ - ecozonal categories; Lat - latitude; Long - longitude; $\mathrm{DN}^{\mathrm{e}}$ - sedimentary deposit name; MD - maximum known depth; A - area; SecD - Secchi depth. $T$ (Win) - winter temperature; $T$ (Sum) - summer temperature; $\mathrm{pH}$ (Win) - winter pH; pH (Sum) - summer pH; ORP (Win) - winter redox potential average; ORP (Sum) - summer redox potential; Chl $a-$ summer surface chlorophyll $a$. $\mathrm{SRP}$ - soluble reactive phosphorus; $\mathrm{NO}_{3}^{-}-$nitrate; $\mathrm{SO}_{4}^{2-}$ - sulfate; TOC - total organic carbon; $\mathrm{TN}$ - total nitrogen are from $1 \mathrm{~m}$ depth, except data summarized from other investigators $\mathrm{g}, \mathrm{h}$. TOCS - total organic carbon in surface sediments; TNS - total nitrogen in surface sediments. Error terms are the standard deviation. ND indicates not determined; CF indicates lake completely frozen; " <" indicates below detection limit; "-" indicates no standard deviation due a sample size of 1 .

\begin{tabular}{|c|c|c|c|c|c|c|c|c|c|c|c|c|}
\hline$N$ & Name & $\mathrm{Y} / \mathrm{NY}^{\mathrm{a}, \mathrm{b}}$ & $\mathrm{TSI}^{\mathrm{c}}$ & $E C^{d}$ & Lat $\left({ }^{\circ} \mathrm{N}\right)$ & Long $\left({ }^{\circ} \mathrm{W}\right)$ & $\mathrm{DN}^{\mathrm{e}}$ & $\begin{array}{l}\text { MD } \\
(\mathrm{m})\end{array}$ & $\begin{array}{l}\mathrm{A} \\
\left(\mathrm{km}^{2}\right)\end{array}$ & $\begin{array}{l}\text { SecD } \\
(\mathrm{m})\end{array}$ & $\begin{array}{r}T \text { (Win) } \\
\quad\left({ }^{\circ} \mathrm{C}\right)\end{array}$ & $\begin{array}{r}T(\text { Sum }) \\
\left({ }^{\circ} \mathrm{C}\right)\end{array}$ \\
\hline 1 & Big Sky* A31 & NY & $\mathrm{O}$ & ArT & 69.581 & 148.639 & ES & 2.2 & 0.349 & 1.30 & $0.7 \pm 0.2$ & $15.7 \pm 0.9$ \\
\hline 2 & Dragon's Pond* A33 & NY & $\mathrm{O}$ & ArT & 68.795 & 148.843 & GF & 1.5 & 0.010 & 1.30 & $2.4^{\mathrm{f}} \pm 2.2$ & $18.4 \pm 0.9$ \\
\hline 3 & GTH 112 & NY & Mx & ArT & 68.672 & 149.249 & GF & 4.8 & 0.025 & 0.80 & $2.6^{\mathrm{f}} \pm 1.1$ & $11.7 \pm 3.8$ \\
\hline 4 & NE2 & NY & $\mathrm{O}$ & ArT & 68.647 & 149.582 & GMD & 2.7 & 0.067 & 2.70 & $0.4 \pm 0.6$ & $15.3 \pm 0.6$ \\
\hline 5 & E6 & NY & $\mathrm{O}$ & ArT & 68.643 & 149.440 & GMD & 2.6 & 0.027 & 2.60 & $3.3^{\mathrm{f}} \pm 1.5$ & $15.8 \pm 1.0$ \\
\hline 6 & E5 Oil Spill A30 & NY & $\mathrm{O}$ & ArT & 68.642 & 149.458 & GMD & 11.9 & 0.116 & 3.10 & $2.8^{\mathrm{f}} \pm 1.3$ & $10.8 \pm 4.2$ \\
\hline 8 & E1 & NY & UO & ArT & 68.626 & 149.555 & GMD & 6.4 & 0.026 & 2.55 & $2.4 \pm 0.8$ & $12.4 \pm 3.7$ \\
\hline 9 & Autumn* A35 & NY & UO & ArT & 68.462 & 149.393 & GMD & 7.5 & 0.057 & 4.51 & $0.45^{\mathrm{f}} \pm 4.4$ & $13.5 \pm 1.9$ \\
\hline 10 & Julieta* A27 & NY & UO & ArT & 68.447 & 149.369 & GMD & 7.0 & 0.051 & 3.40 & $-1.4^{\mathrm{f}} \pm 2.0$ & $14.3 \pm 1.2$ \\
\hline 11 & El Fuego* A36 & NY & UO & FoT & 67.666 & 149.716 & GMD & 2.5 & 0.057 & 2.71 & $2.9^{\mathrm{f}} \pm 4.5$ & $15.7 \pm 1.2$ \\
\hline 12 & Jonas* A26 & NY & UO & FoT & 67.647 & 149.722 & GMD & 4.2 & 0.170 & 0.95 & $-0.2 \pm 0.0$ & $14.2 \pm 4.8$ \\
\hline 13 & Augustine Zoli* A25 & NY & $\mathrm{O}$ & FoT & 67.138 & 150.349 & $\mathrm{~F}$ & 3.0 & 0.069 & 1.12 & ND & $17.3 \pm 1.7$ \\
\hline 19 & Doughnut*a & NY & $\mathrm{O}$ & NBF & 64.899 & 147.908 & $\mathrm{E}$ & 3.8 & 0.034 & 1.59 & $0.7 \pm 0.8$ & $22.2 \pm 2.2$ \\
\hline 20 & Killarney* & $\mathrm{Y}$ & Mx & NBF & 64.870 & 147.901 & $\mathrm{E}$ & 2.1 & 0.008 & 0.50 & $0.6 \pm 0.7$ & $7.8 \pm 4.5$ \\
\hline 21 & Smith A13 ${ }^{\mathrm{a}}$ & NY & Mx & NBF & 64.865 & 147.868 & $\mathrm{E}$ & 4.4 & 0.094 & 0.50 & $0.5 \pm 0.7$ & $19.0 \pm 1.7$ \\
\hline 22 & Stevens Pond* & $\mathrm{Y}$ & $\mathrm{Mx}$ & NBF & 64.863 & 147.871 & $\mathrm{E}$ & 1.1 & 0.002 & 0.50 & $\mathrm{CF}$ & $17.6 \pm 1.6$ \\
\hline 23 & Duece A2 & $\mathrm{Y}$ & $\mathrm{Mx}$ & NBF & 64.863 & 147.942 & $\mathrm{E}$ & 6.0 & 0.023 & 0.79 & $0.9 \pm 0.6$ & $11.4 \pm 7.0$ \\
\hline 24 & Ace A1 & $\mathrm{Y}$ & $\mathrm{Mx}$ & NBF & 64.862 & 147.937 & $\mathrm{E}$ & 9.0 & 0.077 & 1.26 & $2.9 \pm 0.9$ & $11.6 \pm 6.3$ \\
\hline 25 & Rosie Creek* & $\mathrm{Y}$ & $\mathrm{Mx}$ & NBF & 64.770 & 148.079 & $\mathrm{E}$ & 3.7 & 0.004 & 1.46 & $0.0 \pm 0.3$ & $11.9 \pm 2.4$ \\
\hline 26 & Monasta $\mathrm{A} 37^{\mathrm{a}}$ & NY & $\mathrm{Mx}$ & NBF & 64.741 & 148.276 & MAC & 5.6 & 0.005 & 0.43 & ND & $8.8 \pm 5.6$ \\
\hline 27 & 91 Lake* & NY & $\mathrm{O}$ & NBF & 63.848 & 148.973 & $\mathrm{~F}$ & 0.5 & 0.066 & 1.40 & ND & $15.3 \pm 0.7$ \\
\hline 28 & Otto & NY & $\mathrm{O}$ & FoT & 63.842 & 149.037 & GMD & 3.1 & 0.515 & 1.60 & $1.6 \pm 1.3$ & $12.0 \pm 6.4$ \\
\hline 29 & Floatplane* A16 & NY & $\mathrm{O}$ & FoT & 63.394 & 148.670 & GL & 5.0 & 0.103 & 1.20 & $3.9^{\mathrm{f}} \pm 1.5$ & $13.1 \pm 1.3$ \\
\hline 30 & Nutella* A39 & NY & $\mathrm{O}$ & $\mathrm{AlT}$ & 63.215 & 147.678 & I & 9.4 & 0.020 & 3.10 & $3.4^{\mathrm{f}} \pm 1.1$ & $10.2 \pm 3.4$ \\
\hline 39 & Engineer A45 & NY & $\mathrm{O}$ & SBF & 60.478 & 150.323 & GMD & 3.9 & 0.909 & 1.60 & $0.4 \pm 0.6$ & $16.4 \pm 1.2$ \\
\hline \multirow[t]{3}{*}{40} & Lower Ohmer A44 & NY & $\mathrm{O}$ & SBF & 60.456 & 150.317 & GMD & 28.0 & 0.471 & 2.70 & $3.6^{\mathrm{f}} \pm 0.5$ & $11.6 \pm 3.7$ \\
\hline & Yedoma $^{\mathrm{i}}$ & - & - & - & - & - & - & $4.2^{\mathrm{k}}$ & $0.022^{\mathrm{k}}$ & $0.82^{\mathrm{k}}$ & $1.1^{\mathrm{k}, \mathrm{n}} \pm 1.0$ & $11.3^{\mathrm{k}} \pm 4.5$ \\
\hline & Non-yedoma ${ }^{\mathrm{j}}$ & - & - & - & - & - & - & $7.6^{\mathrm{k}}$ & $0.267^{1}$ & $2.39^{1}$ & $1.6^{\mathrm{k}, \mathrm{o}} \pm 1.3$ & $14.9^{\mathrm{l}, \mathrm{p}} \pm 3.0$ \\
\hline
\end{tabular}


Table 1. Continued.

\begin{tabular}{|c|c|c|c|c|c|c|c|c|}
\hline$N$ & Name & $\begin{array}{l}\mathrm{pH} \\
\text { (Win) }\end{array}$ & $\begin{array}{l}\mathrm{pH} \\
\text { (Sum) }\end{array}$ & $\begin{array}{l}\text { ORP (Win) } \\
(\mathrm{mV})\end{array}$ & $\begin{array}{l}\text { ORP (Sum) } \\
(\mathrm{mV})\end{array}$ & $\begin{array}{l}\text { Chl } a \\
\left(\mu \mathrm{gL}^{-1}\right)\end{array}$ & $\begin{array}{r}\text { SRP } \\
\left(\mu \mathrm{PL}^{-1}\right)\end{array}$ & $\begin{array}{l}\mathrm{NO}_{3}^{-} \\
\left(\mathrm{mgNO}_{3}^{-}-\right. \\
\left.\quad \mathrm{NL}^{-1}\right)\end{array}$ \\
\hline 2 & Dragon's Pond* A33 & ND & $7.7 \pm 0.5$ & ND & $304 \pm 78$ & $4.7 \pm 4.2$ & $5.9^{\mathrm{g}}$ & ND \\
\hline 3 & GTH 112 & ND & $7.2 \pm 0.7$ & ND & $264 \pm 69$ & $45.9 \pm 7.4$ & ND & $<0.01$ \\
\hline 4 & NE2 & $6.6 \pm 0.1$ & $7.9 \pm 0.6$ & $322 \pm 17$ & $299 \pm 66$ & $3.7 \pm 4.6$ & $1.3^{\mathrm{h}}$ & ND \\
\hline 6 & E5 Oil Spill A30 & ND & $7.1 \pm 0.8$ & ND & $322 \pm 64$ & $13.5 \pm 2.9$ & $1.8^{\mathrm{h}}$ & ND \\
\hline 7 & Toolik A28 & $6.9 \pm 0.1$ & $7.9 \pm 0.8$ & $303 \pm 32$ & $308 \pm 75$ & $1.5 \pm 0.4$ & $1.6^{\mathrm{h}}$ & $<0.01$ \\
\hline 8 & E1 & $7.0 \pm 0.1$ & $9.1 \pm 0.4$ & $283 \pm 58$ & $231 \pm 71$ & $1.3^{\mathrm{g}} \pm-$ & $1.1^{\mathrm{h}}$ & $<0.01$ \\
\hline 9 & Autumn* A35 & ND & $8.2 \pm 0.6$ & ND & $303 \pm 45$ & $2.9 \pm 2.4$ & $2.8^{\mathrm{g}}$ & ND \\
\hline 10 & Julieta* A27 & ND & $8.5 \pm 0.6$ & ND & $318 \pm 34$ & $3.4 \pm 3.8$ & $3.6^{\mathrm{g}}$ & $<0.01$ \\
\hline 11 & El Fuego* A36 & ND & $8.8 \pm 0.4$ & ND & $271 \pm 50$ & $1.2 \pm 0.1$ & ND & ND \\
\hline 16 & Eugenia* & $6.3 \pm 0.0$ & $7.0 \pm 0.3$ & $118 \pm 9$ & $314 \pm 45$ & $41.9 \pm 2.4$ & ND & $<0.01$ \\
\hline 17 & Vault* & $7.7 \pm 0.7$ & $8.6 \pm 0.8$ & $75 \pm 62$ & $156 \pm 87$ & $35.0 \pm 15.0$ & ND & ND \\
\hline 18 & Goldstream* & $7.4 \pm 0.6$ & $7.9 \pm 0.7$ & $117 \pm 118$ & $216 \pm 134$ & $31.0 \pm 14.5$ & 9.7 & 0.01 \\
\hline 19 & Doughnut*a & $6.8 \pm 0.1$ & $7.7 \pm 0.6$ & $189 \pm 56$ & $254 \pm 77$ & $113.4 \pm 0.0$ & ND & ND \\
\hline 20 & Killarney* & $7.0 \pm 0.1$ & $7.6 \pm 0.7$ & $66 \pm 45$ & $316 \pm 99$ & ND & 10.2 & 0.01 \\
\hline 21 & Smith $A 13^{\mathrm{a}}$ & $6.5 \pm 0.0$ & $8.3 \pm 1.1$ & $98 \pm 16$ & $187 \pm 99$ & $44.7 \pm 0.6$ & $16.2^{\mathrm{g}}$ & $<0.01$ \\
\hline 22 & Stevens Pond* & $\mathrm{CF}$ & $8.4 \pm 1.7$ & $\mathrm{CF}$ & $212 \pm 136$ & $43.7 \pm 13.4$ & $\mathrm{CF}$ & $\mathrm{CF}$ \\
\hline 23 & Duece A2 & $7.2 \pm 0.0$ & $9.2 \pm 0.4$ & $58 \pm 10$ & $-20 \pm 94$ & $1.5^{\mathrm{g}} \pm-$ & $60.2^{\mathrm{g}}$ & 0.32 \\
\hline 24 & Ace A1 & $7.1 \pm 0.0$ & $8.1 \pm 1.0$ & $68 \pm 15$ & $116 \pm 161$ & $54.0^{\mathrm{g}} \pm-$ & $31.5^{\mathrm{g}}$ & 0.02 \\
\hline 25 & Rosie Creek* & $7.1 \pm 0.0$ & $8.1 \pm 1.0$ & $33 \pm 19$ & $245 \pm 127$ & $45.3 \pm 1.9$ & ND & ND \\
\hline 26 & Monasta $\mathrm{A} 37^{\mathrm{a}}$ & ND & $6.3 \pm 0.1$ & ND & $160 \pm 119$ & ND & $24.9^{\mathrm{g}}$ & ND \\
\hline 34 & Big Merganser A49 & $6.4 \pm 0.4$ & $7.1 \pm 0.3$ & $321 \pm 38$ & $325 \pm 49$ & $7.4 \pm 1.1$ & $4.4^{\mathrm{g}}$ & $<0.01$ \\
\hline 35 & Rainbow A48 & $7.0 \pm 0.0$ & $7.7 \pm 0.6$ & $241 \pm 62$ & $289 \pm 85$ & $12.6 \pm 0.4$ & $4.8^{\mathrm{g}}$ & $<0.01$ \\
\hline 36 & Dolly Varden A47 & ND & $7.1 \pm 0.3$ & ND & $282 \pm 22$ & $3.7 \pm 0.5$ & $2.1^{\mathrm{g}}$ & $<0.01$ \\
\hline 37 & Abandoned Cabin* A50 & $6.0 \pm 0.5$ & $6.3 \pm 0.2$ & $299 \pm 113$ & $338 \pm 33$ & $10.2 \pm 1.1$ & $2.3^{\mathrm{g}}$ & 0.04 \\
\hline 38 & Scout A46 & $6.3 \pm 0.4$ & $7.0 \pm 0.4$ & $290 \pm 36$ & $347 \pm 25$ & $10.9 \pm 0.4$ & $4.7^{\mathrm{g}}$ & 0.01 \\
\hline 39 & Engineer A45 & $6.7 \pm 0.3$ & $7.8 \pm 0.4$ & $273 \pm 31$ & $267 \pm 43$ & $7.0 \pm 0.2$ & $7.5^{\mathrm{g}}$ & $<0.01$ \\
\hline \multirow[t]{3}{*}{40} & Lower Ohmer A44 & ND & $7.5 \pm 0.5$ & ND & $379 \pm 50$ & $9.9 \pm 0.5$ & $1.8^{\mathrm{g}}$ & $<0.01$ \\
\hline & Yedoma $^{\mathrm{i}}$ & $7.1^{\mathrm{k}, \mathrm{m}} \pm 0.5$ & $8.2^{\mathrm{k}, \mathrm{m}} \pm 0.9$ & $84^{\mathrm{k}, \mathrm{m}} \pm 27$ & $187^{\mathrm{k}, \mathrm{m}} \pm 118$ & $34.5^{\mathrm{k}} \pm 18.0$ & $27.9^{\mathrm{k}}$ & $0.09^{\mathrm{k}}$ \\
\hline & Non-yedoma ${ }^{\mathrm{j}}$ & $6.7^{1, o} \pm 0.5$ & $7.7^{\mathrm{k}, \mathrm{p}} \pm 0.7$ & $222^{1, o} \pm 95$ & $295^{1, p} \pm 51$ & $14.5^{1} \pm 21.8$ & $5.3^{1}$ & $0.02^{\mathrm{k}}$ \\
\hline
\end{tabular}


Table 1. Continued.

\begin{tabular}{|c|c|c|c|c|c|c|}
\hline$N$ & Name & $\begin{array}{l}\mathrm{SO}_{4}^{2-} \\
\left(\mathrm{mg} \mathrm{SO}_{4}^{2-}-\mathrm{SL}^{-1}\right)\end{array}$ & $\begin{array}{l}\text { TOC } \\
\left(\mathrm{mgL}^{-1}\right)\end{array}$ & $\begin{array}{l}\mathrm{TN} \\
\left(\mathrm{mg} \mathrm{L}^{-1}\right)\end{array}$ & $\begin{array}{r}\text { TOCS } \\
(\%)\end{array}$ & $\begin{array}{r}\text { TNS } \\
(\%)\end{array}$ \\
\hline 1 & Big Sky* A31 & $<0.04$ & 16.48 & 1.3 & $1.8 \pm 0.0$ & $1.5 \pm 0.3$ \\
\hline 2 & Dragon's Pond* A33 & $6.20^{\mathrm{g}}$ & 16.98 & 3.2 & $6.2 \pm 0.8$ & $2.2 \pm 0.3$ \\
\hline 3 & GTH 112 & 0.51 & ND & ND & ND & ND \\
\hline 4 & NE2 & ND & 0.93 & 0.2 & $2.9 \pm 0.5$ & $1.1 \pm 0.2$ \\
\hline 5 & E6 & ND & ND & ND & $3.5 \pm 0.5$ & $1.4 \pm 0.1$ \\
\hline 6 & E5 Oil Spill A30 & $<0.04$ & ND & $0.2^{\mathrm{g}}$ & $8.1 \pm 0.1$ & $0.7 \pm 0.0$ \\
\hline 7 & Toolik A28 & $<0.04$ & 0.70 & 0.2 & $7.8 \pm 1.3$ & $0.8 \pm 0.2$ \\
\hline 8 & E1 & $<0.04$ & 0.18 & 0.2 & ND & ND \\
\hline 9 & Autumn* A35 & $5.30^{\mathrm{g}}$ & 3.66 & 0.4 & ND & ND \\
\hline 10 & Julieta* A27 & $<0.04$ & 0.71 & $0.3^{\mathrm{g}}$ & $0.8 \pm 0.8$ & $0.4 \pm 0.2$ \\
\hline 11 & El Fuego* A36 & $40.40^{\mathrm{g}}$ & ND & 0.4 & $1.1 \pm 0.2$ & $0.5 \pm 0.1$ \\
\hline 12 & Jonas* A26 & 0.25 & 0.89 & 0.7 & $2.9 \pm 2.2$ & $1.1 \pm 0.8$ \\
\hline 13 & Augustine Zoli* A25 & $<0.04$ & 4.42 & 0.9 & $3.0 \pm 0.4$ & $1.1 \pm 0.1$ \\
\hline 14 & Ping* & 0.18 & 12.38 & 0.9 & ND & ND \\
\hline 15 & Grayling A24 & 0.86 & 8.34 & 1.0 & $7.3 \pm 1.8$ & $0.3 \pm 0.1$ \\
\hline 16 & Eugenia* & $<0.04$ & 16.51 & 0.8 & $22.0 \pm 0.3$ & ND \\
\hline 17 & Vault* & ND & ND & ND & $8.0 \pm 1.2$ & ND \\
\hline 18 & Goldstream* & 0.30 & 45.30 & 3.0 & $4.2 \pm 0.6$ & ND \\
\hline 19 & Doughnut*a & ND & ND & ND & $24.0 \pm 2.2$ & ND \\
\hline 20 & Killarney* & 0.01 & 18.12 & 2.3 & $3.5 \pm 2.5$ & $0.2 \pm 0.1$ \\
\hline 21 & Smith $A 13^{\mathrm{a}}$ & 11.60 & ND & $1.3^{\mathrm{g}}$ & ND & ND \\
\hline 22 & Stevens Pond* & $\mathrm{CF}$ & $\mathrm{CF}$ & $\mathrm{CF}$ & $\mathrm{CF}$ & $\mathrm{CF}$ \\
\hline 23 & Duece A2 & 1.10 & ND & $2.4^{\mathrm{g}}$ & $5.0 \pm 0.7$ & $1.8 \pm 0.7$ \\
\hline 24 & Ace A1 & 0.34 & ND & $1.3^{\mathrm{g}}$ & $2.6 \pm 2.5$ & $1.0 \pm 0.9$ \\
\hline 25 & Rosie Creek* & ND & ND & ND & ND & ND \\
\hline 26 & Monasta $\mathrm{A} 37^{\mathrm{a}}$ & ND & $58.80^{\mathrm{g}}$ & $2.2^{\mathrm{g}}$ & ND & ND \\
\hline 27 & 91 Lake* & ND & ND & ND & ND & ND \\
\hline 28 & Otto & 0.20 & 3.63 & 0.8 & $8.8 \pm 1.3$ & ND \\
\hline 29 & Floatplane* A16 & ND & ND & $0.5^{\mathrm{g}}$ & ND & ND \\
\hline 30 & Nutella* A39 & ND & ND & $0.3^{\mathrm{g}}$ & ND & ND \\
\hline 31 & Swampbuggy A18 & ND & ND & $0.3^{\mathrm{g}}$ & ND & ND \\
\hline 32 & Montana A40 & $<0.04$ & 0.16 & 0.3 & ND & ND \\
\hline 33 & Rainbow Shore* A41 & 0.33 & 52.20 & 0.1 & $38.8 \pm 15.2$ & ND \\
\hline 34 & Big Merganser A49 & 12.32 & 2.38 & 0.3 & ND & ND \\
\hline 35 & Rainbow A48 & 2.30 & 1.05 & 0.2 & ND & ND \\
\hline 36 & Dolly Varden A47 & 1.70 & ND & $0.2^{\mathrm{g}}$ & $6.2 \pm 0.7$ & ND \\
\hline 37 & Abandoned Cabin* A50 & 0.76 & ND & $0.3^{\mathrm{g}}$ & $25.7 \pm 0.4$ & ND \\
\hline 38 & Scout A46 & 0.78 & 2.58 & 0.4 & $23.0 \pm 0.1$ & ND \\
\hline 39 & Engineer A45 & $<0.04$ & 5.71 & 0.6 & $7.6 \pm 1.2$ & ND \\
\hline 40 & Lower Ohmer A44 & 2.50 & ND & $0.3^{\mathrm{g}}$ & ND & ND \\
\hline & Yedoma $^{\mathrm{i}}$ & $0.44^{\mathrm{k}}$ & $26.6^{\mathrm{k}}$ & $2.0^{\mathrm{k}}$ & $7.6^{\mathrm{k}} \pm 7.3$ & $1.0^{\mathrm{k}} \pm 0.8$ \\
\hline & Non-yedoma ${ }^{\mathrm{j}}$ & $5.39^{\mathrm{k}}$ & $10.1^{1}$ & $0.6^{1}$ & $10.0^{\mathrm{k}} \pm 10.6$ & $1.0^{\mathrm{k}} \pm 0.6$ \\
\hline
\end{tabular}

\footnotetext{
a Doughnut Lake, a partially drained lake (uncalibrated ${ }^{14} \mathrm{C}$ age $1190 \pm 20 \mathrm{yr}$ BP, measured on outer wood of an in situ, dead tree near the lake center); Smith Lake, and Monasta Lake were included in the non-yedoma lake classification. While Doughnut and Monasta lakes likely formed in yedoma permafrost originally, following partial drainage events, they no longer appear to be influenced by active yedoma thaw along the margin. Smith Lake is thought to have formed as part of a previous river drainage network (V. Alexander, personal communication, 2011)

${ }^{\mathrm{b}}$ Permafrost soil type: $\mathrm{Y}$ - yedoma; $\mathrm{NY}$ - non-yedoma.

c Trophic state index: UO - ultraoligotrophic; O - oligotrophic; M - mesotrophic; E - eutrophic; $\mathrm{Mx}$ - mixotrophic.

${ }^{d}$ Ecozonal categories according to Gregory Eaves et al. (2000): ArT - Arctic tundra; AlT - alpine tundra; FoT - forest tundra; NBF northern boreal forest; SBF - southern boreal forest.

e Deposit name: ES - eolian silt; GF - glaciofluvial; GMD - old glacial moraines and drift; F - fluvial; MAC - mountain alluvium and colluvium; E - eolian; GL - glaciolacustrine (Jorgenson et al., 2008).

${ }^{\mathrm{f}}$ Winter (October-April) temperature average from HOBO measurements.

$\mathrm{g}$ Data from Gregory Eaves et al. (2000).

h Data from Giblin et al. (2009); water-column average.

${ }^{\mathrm{i}}$ Average from yedoma lakes (lake \#25 excluded).

$\mathrm{j}$ Average from non-yedoma lakes.

$\mathrm{k}, \mathrm{l}$ Different letters indicate a significant difference between yedoma and non-yedoma means.

$\mathrm{m}, \mathrm{n}$ Different letters indicate a significant difference between summer and winter means in yedoma lakes for temperature, $\mathrm{pH}$ and $\mathrm{ORP}$ (Mann-Whitney $U$ test).

o,p Different letters indicate a significant difference between summer and winter means in non-yedoma lakes for temperature, $\mathrm{pH}$ and $\mathrm{ORP}$ (Mann-Whitney $U$ test).
} 


\subsection{Water-dissolved $\mathrm{CH}_{4}, \mathrm{CO}_{2}$, and $\mathrm{O}_{2}$}

Sampling of lake water was done offshore and usually near the center of each lake at one to nine distributed depths throughout the water column for dissolved $\mathrm{CH}_{4}$ and $\mathrm{CO}_{2}$ concentrations and at $0.5 \mathrm{~m}$ depth intervals for $\mathrm{O}_{2}$ concentrations during winter and summer. In lakes shallower than $1 \mathrm{~m}$ we sampled only one depth within $25 \mathrm{~cm}$ of the lake bottom. In the field we measured $\mathrm{CH}_{4}$ concentration via the headspace equilibration tunable diode laser spectroscopy (HE-TDLAS) method (Sepulveda-Jauregui et al., 2012) using a GasFinder 2.0 (Boreal Laser Inc., Edmonton, Canada; Appendix A1). Additionally, we determined concentrations of headspace $\mathrm{CH}_{4}$ and $\mathrm{CO}_{2}$ in bottles of lake water in the laboratory following Kling (2010) using a GC-2014 gas chromatograph (Shimadzu, Addison, Illinois, USA) equipped with a flame ionization detector and a PLOT alumina column (detector temperature $250^{\circ} \mathrm{C}$, oven $40^{\circ} \mathrm{C}$, high-purity helium as carrier gas). Strong correlation between the GasFinder and bottle headspace methods was reported previously by Sepulveda-Jauregui et al. (2012). Dissolved $\mathrm{O}_{2}$ concentrations were measured in the field with a luminescence sensor connected to a calibrated multiparametric probe Hydrolab DataSonde (Hach LDO, Loveland, Colorado, USA).

\section{3 $\mathrm{CH}_{4}$ and $\mathrm{CO}_{2}$ diffusion flux}

We estimated the diffusion flux of $\mathrm{CH}_{4}$ and $\mathrm{CO}_{2}$ $\left(\mathrm{g} \mathrm{m}^{-2} \mathrm{yr}^{-1}\right)$ based on the once per summer measurement of dissolved $\mathrm{CO}_{2}$ and $\mathrm{CH}_{4}$ in surface water from each lake and extrapolating results to the summertime open-water period. We applied Fick's law to our measurements of dissolved $\mathrm{CO}_{2}$ and $\mathrm{CH}_{4}$ in surface water following the boundary layer method of Kling et al. (1992):

Diffusion flux $=T \times D \times z^{-1} \times\left(C_{\mathrm{w}}-C_{\mathrm{eq}}\right)$,

where $T$ is the conversion factor from seconds to years (31 536000); $D$ is the molecular diffusivity of $\mathrm{CH}_{4}$ or $\mathrm{CO}_{2}$ $\left(\mathrm{m}^{2} \mathrm{~s}^{-1}\right)$ following Kling et al. (1992); $z(\mathrm{~m})$ is the thickness of the surface boundary layer, assumed to be $200 \mu \mathrm{m}$ as an average for Alaskan lakes following Kling et al. (1992); $C_{\mathrm{w}}$ is the measured gas concentration at the bottom of the boundary layer $\left(\mathrm{g} \mathrm{m}^{-3}\right)$; and $C_{\mathrm{eq}}$ is the equilibrium gas concentration in surface lake water $\left(\mathrm{g} \mathrm{m}^{-3}\right)$ exposed to the atmosphere at the top of the boundary layer. We calculated $C_{\mathrm{w}}$ and $C_{\mathrm{eq}}$ using measured surface water temperatures, Henry's law constants, and temperature dependence constants for $\mathrm{CH}_{4}$ and $\mathrm{CO}_{2}$, respectively (NIST, 2011). We acknowledge that wind speed and heat exchange vary over different timescales and that they have a large effect on the gas exchange coefficient (Cole and Caraco, 1998; Tedford et al., 2014) and thus on the relative importance of diffusion emission from lakes. However, due to lacking wind speed and heat exchange data for our study lakes, our calculations are based on the assumption of a constant gas exchange coefficient derived from av- eraged wind speed values from lakes in our northern tundra study region (Kling et al., 1992). Because many of our study lakes are surrounded by trees, the average wind speed at these lakes during the open-water periods is likely more similar to that of the low-wind Mirror Lake, studied by Cole and Caraco (1998). On one lake, Goldstream Lake (forested, interior Alaska), where we had higher temporal resolution data for surface-water-dissolved $\mathrm{CH}_{4}$ concentrations (Greene et al., 2014) during the open-water summer period, we explored the effect of using the average value of the exchange coefficient from Cole and Caraco (1998) instead of Kling et al. (1992) and found that the exchange coefficient calculated from the boundary layer thickness of Kling et al. (1992) differed by $2 \%$ from that from Cole and Caraco (1998).

\subsection{Storage flux}

To estimate storage flux, dissolved $\mathrm{CH}_{4}$ and $\mathrm{CO}_{2}$ profiles were measured in spring before the ice began to melt and in summer during ice-free conditions. We multiplied the average concentration of dissolved $\mathrm{CH}_{4}$ and $\mathrm{CO}_{2}$ measured in samples collected from distributed depths in the water column by the height of the unfrozen water column. Storage flux $\left(\mathrm{g} \mathrm{m}^{-2} \mathrm{yr}^{-1}\right)$ was calculated as the difference between total mass of dissolved gas in spring before ice breakup and the total mass of dissolved gas in summer.

\section{5 $\mathrm{CH}_{4}$ and $\mathrm{CO}_{2}$ ebullition from sediments}

We estimated $\mathrm{CH}_{4}$ and $\mathrm{CO}_{2}$ ebullition from sediments associated with discrete seeps following the lake-ice ebullition survey method of Walter Anthony et al. (2010). Seeps are defined as point-source locations of repeated bubbling and identified as A, B, C, and hotspot classes according to distinct patterns of bubbles trapped in lake ice (Appendix A2). To quantify seep ebullition, we removed snow from early winter lake ice to expose ebullition bubble clusters trapped in ice for seep classification, GPS mapping, flux measurements, and gas collection using submerged bubble traps. On foot, we surveyed 9355 individual seeps within 161 plots $\left(30-300 \mathrm{~m}^{2}\right.$ per plot) positioned randomly within both littoral and profundal zones of lakes. In some lakes, ice was opened above the seeps for placement of submerged bubble traps. We retained semi-automated bubble traps placed over individual seeps year-round (Walter Anthony et al., 2010) to provide daily and seasonal ebullition flux data from sediments. Seep classspecific flux rates and bubble $\mathrm{CH}_{4}$ and $\mathrm{CO}_{2}$ concentrations measured on a subset of seeps were applied to all mapped seeps to estimate whole-lake ebullition rates, indexed by Julian day of the year (Appendix A2). These fluxes represent bubbling rates from sediments as measured at the lake surface, not necessarily direct ebullition to the atmosphere. The following two sections describe the fate of ebullition bubbles during the ice-cover and ice-free seasons. 


\subsection{Ice-bubble storage (IBS) flux}

During the open-water (ice-free) summer season, ebullition bubbles reaching the lake surface release $\mathrm{CH}_{4}$ directly to the atmosphere (direct ebullition). In winter, lake ice impedes direct ebullition emissions. Many ebullition bubbles reaching the top of the water column hit the underside of lake ice, come to rest, and exchange gases with the water column until the downward-growing ice encapsulates the bubbles. Since lake water is typically undersaturated in $\mathrm{CH}_{4}$ with respect to the $\mathrm{CH}_{4}$ concentration (40-90\%) of most ebullition bubbles (Sepulveda-Jauregui et al., 2012), $\mathrm{CH}_{4}$ readily diffuses out of bubbles into the lake water column.

We collected 37 samples of ebullition bubbles trapped as pockets in lake ice from five Alaskan lakes, expanding upon the lake ice-bubble data set of Walter et al. (2008). Additionally, we opened the lake ice and placed bubble traps beneath ice, above seeps, to sample "fresh" ebullition bubbles at the lake surface before they are impeded by ice ( $n=2-41$ seeps per lake; total of 560 samples). This allowed us to compare concentrations of $\mathrm{CH}_{4}$ in ice-trapped bubbles ( $n=2-8$ seeps per lake) to gas concentrations in "fresh" bubbles prior to ice entrapment.

Numerical modeling informed by detailed field studies of $\mathrm{CH}_{4}$ diffusion from ice-trapped bubbles in one of our study lakes, Goldstream Lake (\#18), revealed that $80 \%$ of $\mathrm{CH}_{4}$ in bubbles trapped by ice dissolves into the lake water column in winter (Greene et al., 2014). The remaining $20 \%$ of $\mathrm{CH}_{4}$ ebullition trapped by ice is released to the atmosphere, either from hotspot seep sites that open periodically throughout the winter or from A, B, and C seep sites as ice melts in spring (i.e., IBS emissions). With input of observed ice-growth rates on a subset of lakes in each of the three study regions and mean monthly atmospheric temperatures during 2003-2013 (US National Weather Service), we employed this model to calculate a first-order estimate of IBS in 34 of the 40 study lakes in which we had measurements of both seep ebullition and water-column dissolved $\mathrm{CH}_{4}$ concentrations, which affect the $\mathrm{CH}_{4}$ dissolution rate from bubbles. We linearly interpolated between measured surface $\mathrm{CH}_{4}$ concentrations in the summer and spring to estimate water-column $\mathrm{CH}_{4}$ concentrations during the ice-cover period. The decrease in the volume of ice-trapped bubbles in each lake, as calculated by this model, was used together with the decrease in their $\mathrm{CH}_{4}$ concentration, calculated from our measurements of fresh vs. ice-trapped bubbles, to determine the IBS flux for each lake.

\subsection{Direct ebullition in winter and summer}

Since ice-bubble pockets above A-, B-, and C-type seeps open approximately 1 month prior to complete disappearance of lake ice in spring (K. M. Walter Anthony, unpublished data, 2014; Greene et al., 2014), we assume in our calculations that subsequent ebullition by seeps releases fresh bubbles directly to the atmosphere through open holes during this spring melt period. Particularly high bubbling rates from "hotspot" seeps maintain ice-free conditions above these point sources of bubbling, allowing for direct ebullition to the atmosphere when air temperature is higher than $-15^{\circ} \mathrm{C}$ (Zimov et al., 2001; Greene et al., 2014). In interior Alaska, the only region where hotspot seeps were observed, mean monthly temperatures from 2003 to 2013 indicated that on average, wintertime direct ebullition from hotspots occurs for several weeks post-freeze-up in October and in spring from February until ice melt in May. These shoulder seasons of bubble emissions through open holes in lake ice are consistent with our field observations. However, warm temperature anomalies or heavy snowfall events can also open hotspots at other times (on the scale of days) during winter (K. M. Walter Anthony, personal observation, 2014; Zimov et al., 2001; Greene et al., 2014), but these were not included in our calculations. In this study, ebullition from all seep classes during the final month of ice cover and from hotspots during fall and spring shoulder seasons when mean monthly atmospheric temperatures were higher than $-15^{\circ} \mathrm{C}$ (US National Weather Service) together comprised direct ebullition in winter.

Direct ebullition in summer was estimated as the product of average seep densities on each lake and the sum of daily ebullition measured in bubble traps placed on representative seeps of each class in a subset of lakes during the open-water summer period (Sect. 2.5).

\subsection{Seasonal and mean annual emissions}

We estimated mean annual emissions from lakes as the sum of various modes of emissions seasonally: (1) direct ebullition from all seeps and diffusion from the water column in summer (ice-free period); (2) winter (ice-cover period) direct ebullition emissions through ice-free hotspot seeps during shoulder seasons and from all open seeps during the final month of the spring ice-melt season; and (3) spring emissions as the sum of, first, the release of IBS (ebullition seep gases trapped by lake ice) before lake ice disappears and, second, the release of lake water column storage of dissolved gases, previously described by Michmerhuizen et al. (1996), Phelps et al. (1998), and Bastviken et al. (2004), when ice melts. We acknowledge that our calculations contain uncertainty associated with the assumption that single-day measurements of dissolved $\mathrm{CO}_{2}$ and $\mathrm{CH}_{4}$ in lakes represent the mean for calculating diffusion flux for the entire open-water period; however, these were the best available data at the time of this study, and a similar approach has been used in numerous other studies reviewed by Bastviken et al. (2011). Due to a paucity of field measurements on the Alaskan lakes, annual emissions estimates do not include background (non-seep) ebullition, which was found to be $25 \%$ of annual emission in Siberian lakes (Walter et al., 2006).

Because lakes were classified according to three geographic zones based on climate and permafrost, the average 
timing of ice cover was used to estimate the seasonal differences between $\mathrm{CH}_{4}$ and $\mathrm{CO}_{2}$ emissions for all lakes within each zone. Mean annual ice-on and ice-off dates from were compiled for years 2000-2012 for study lakes near Toolik Field Station in the northern region (1 October-18 June), our own observations of interior Alaska study lakes near Fairbanks from years 2008 to 2012 (8 October-9 May), and from Arp et al. (2013) and the National Park Service Inventory and Monitoring Program during years 2000-2013 for southern region lakes near Denali National Park (1 October23 May) and south-central Alaska, south of the Alaska Range (15 November -7 May).

\subsection{Physical and chemical limnology}

We measured the physicochemical properties of lakes during winter and summer field campaigns at the same locations where dissolved gases were measured. Measurements of in situ water properties along vertical depth profiles in lakes included temperature, $\mathrm{pH}$, oxidation reduction potential (ORP), and chlorophyll $a$ (Chl $a$ ) obtained using a calibrated multiparametric probe Hydrolab DataSonde (Hach, Loveland, Colorado, USA). For a subset of lakes in each region, we used temperature data loggers (UA-001-08, Onset HOBO, Bourne, Massachusetts, USA) to record water temperature year-round in 5 min intervals at two depths (1 m water depth and lake bottom). Secchi disk depth (SecD) was measured with a $0.2 \mathrm{~m}$ Secchi disk. We collected water samples for ex situ analyses using a horizontal 2.2 L Van Dorn bottle (WILDCO, Yulee, Florida, USA). The concentrations of dissolved nitrate $\left(\mathrm{NO}_{3}^{-}\right)$, soluble reactive phosphorus (SRP), and sulfate $\left(\mathrm{SO}_{4}^{2-}\right)$ in lake water were measured with a high-performance liquid chromatograph equipped with an electrochemical detector (ED40 Dionex, Dionex, USA). We determined total organic carbon (TOC; used to approximate DOC following Wetzel , 2001, and Weyhenmeyer and Karlsson, 2009) and total nitrogen (TN) with a total carbon and nitrogen analyzer (Shimadzu TOC-Vcsh equipped with TNM1 module, Shimadzu, Japan).

Trophic state indexes (TSIs), calculated from Chl $a$, SecD, and SRP, were used to estimate the trophic states of the lakes (Carlson, 1977). Since total phosphorus (TP) is typically used in TSI calculations, our calculation is an approximation of trophic state. However, we do not expect the use of SRP instead of TP to have a large effect on our results, since Chl $a$ is the primary index for trophic state classification (Carlson and Simpson, 1996). Furthermore, SRP is the more biologically reactive form of phosphorous in lake water lake, and has been shown to be a good predictor of trophic status (Stendick and Hall, 2003; Haberman and Haldna, 2014).

We classified some lakes as mixotrophic since our field and laboratory observations of brown water color (high DOC), low SecD, high nutrients, high epilimnetic Chl $a$ concentrations, abundant macrophytes, and anoxic hypolimnion matched the definition of mixotrophic provided by Williamson et al. (1999). In these lakes, water had a darkbrown color resulting from high concentrations of DOC, presumably from humic substances and organic acids leached from litter and soils in their watersheds. Rather than recognizing two separate classes of high-DOC lakes (mixotrophy with high nutrient concentrations vs. dystrophy with low nutrient concentrations), Wetzel (2001) considered all high-DOC lakes as dystrophic. Wetzel (2001) explained that the productivity of most dystrophic lakes has classically been described as low; however, more detailed examinations indicated that chlorophyll concentration (phytoplankton biomass) was significantly higher in the more shallow photic zone of brown-water lakes than in clear lakes when expressed per volume of epilimnion. We did not quantify macrophyte biomass, but our qualitative observation of a higher abundance of submerged and emergent plants growing in the brown-water lakes is also consistent with Wetzel's description of littoral plants often contributing significantly to lake ecosystem metabolism in dystrophic (mixotrophic) lakes.

Surface sediment samples (1-5 cm depth) were collected in summer 2008 from a subset of lakes using a $6.6 \mathrm{~cm}$ diameter piston hammer corer at multiple locations within individual lakes. Samples were stored under refrigeration and then dried $\left(105^{\circ} \mathrm{C}\right)$ and acidified $(5-15 \mathrm{~mL} 2 \mathrm{~N} \mathrm{HCl})$, and subsequently the top $1 \mathrm{~cm}$ was analyzed for TOC and TN on a Costech ESC 4010 elemental analyzer (Alaska Stable Isotope Facility at the University of Alaska Water and Environmental Research Center). Additional surface lake sediment samples were collected in 2012 from a central lake location using the hammer corer. These sediments were analyzed for moisture content by weighing and drying to $105^{\circ} \mathrm{C}$. We determined organic matter content on a dry weight basis via loss on ignition at $550{ }^{\circ} \mathrm{C}$ (Dean, 1974).

\subsection{Statistical analysis}

Since data were not normally distributed and did not meet the assumption of homoscedasticity, we tested relationships between $\mathrm{CH}_{4}$ and $\mathrm{CO}_{2}$ emissions vs. geographic characteristics and limnological properties for the different lakes using the non-parametric two-tailed Mann-Whitney $U$ test for comparison of two groups and Kruskal-Wallis one-way analysis of variance for comparison of several groups. We followed the Kruskal-Wallis analysis with the multiple-comparison $Z$ value test; differences were significant when the $Z$ value was $>1.96$.

We used single linear regression analysis to quantify relationships between $\mathrm{CH}_{4}$ and $\mathrm{CO}_{2}$ emissions and geographic and limnological properties. For these analyses, data normalization was obtained using logarithm base 10 (log) transformation. Before and after data transformation, normality was assessed by the Shapiro-Wilk test. Regression models were accepted when the $p$ value was $<0.01$. Mean values from full vertical depth profiles of temperature, $\mathrm{pH}$, and ORP, and 


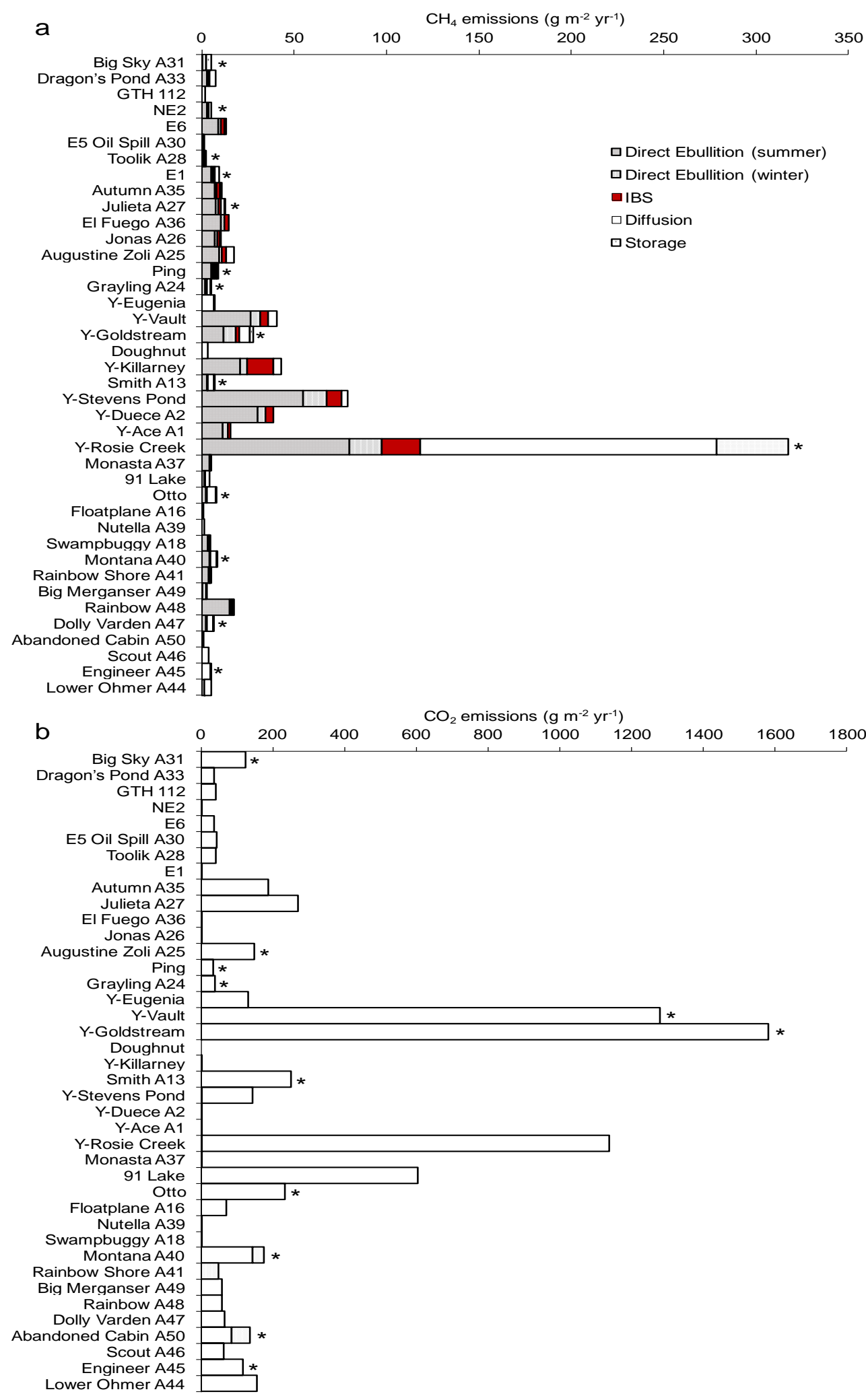

Figure 2. Total annual $\mathrm{CH}_{4}$ (a) and $\mathrm{CO}_{2}$ (b) emissions by mode from 40 lakes along a north-south latitudinal transect in Alaska. Yedoma lakes are indicated by "Y". Lakes for which all emission modes were measured are indicated by “*” (see Table 2). Panels (a) and (b) follow the legend shown in (a). 
from epilimnion measurements for Chl $a$ are shown in Table 1 and were used in these single linear regression analyses. We used the mean winter temperature measured with HOBO data loggers ( $1 \mathrm{~m}$ water depth and lake bottom) to fill data gaps in some northern lakes (Table 1).

Relationships between permafrost type, $\mathrm{CH}_{4}$ ebullition, and lake area were evaluated graphically and by Spearman product-moment correlation coefficients $\left(r_{\mathrm{s}}\right)$. Relationships between lake-bottom water-dissolved $\mathrm{CH}_{4}$, lakebottom water-dissolved $\mathrm{O}_{2}$, and ebullition were evaluated in the same manner.

Statistical analyses were performed with NCSS 2000 Statistical Analysis 193 System software (Number Cruncher Statistical Systems, USA). To fill data gaps, we added additional limnological, geographic, and ecological zone information from the literature to our own measurements (Table 1).

\section{Results}

\subsection{Geographic and limnological patterns of $\mathrm{CH}_{4}$ and $\mathrm{CO}_{2}$ emissions}

Total annual $\mathrm{CH}_{4}$ and $\mathrm{CO}_{2}$ emissions were highly variable, ranging 2 orders of magnitude among lakes (2.0 to $>300 \mathrm{~g} \mathrm{CH}_{4}$ and 34.2 to $>1500 \mathrm{~g} \mathrm{CO}_{2} \mathrm{~m}^{-2} \mathrm{yr}^{-1}$; Table 2, Fig. 2). Among the geographic characteristics presented in Table 1 and $\mathrm{CH}_{4}$ and $\mathrm{CO}_{2}$ emissions presented in Table 2, we found that the type of permafrost soil (yedoma vs. non-yedoma) was the geographic characteristic most closely related to $\mathrm{CH}_{4}$ and $\mathrm{CO}_{2}$ emissions (Table 3). Total annual $\mathrm{CH}_{4}$ emissions from yedoma lakes $\left(44.2 \pm 17.0 \mathrm{~g} \mathrm{~m}^{-2} \mathrm{yr}^{-1}\right.$, mean $\pm \mathrm{SD}, n=7$ lakes, excluding outlier lake \#25) was significantly higher than from non-yedoma lakes $\left(8.0 \pm 4.1 \mathrm{~g} \mathrm{~m}^{-2} \mathrm{yr}^{-1}, n=32\right.$ lakes) (Table 2). Total annual $\mathrm{CO}_{2}$ emissions appeared higher in yedoma $\left(784 \pm 757 \mathrm{~g} \mathrm{~m}^{-2} \mathrm{yr}^{-1}\right.$, mean $\pm \mathrm{SD}, n=8$ lakes, excluding outlier lake \#25) than non-yedoma lakes $\left(137 \pm 129 \mathrm{~g} \mathrm{~m}^{-2} \mathrm{yr}^{-1}, n=32\right.$ lakes) (Table 2); however, due to high variability among lakes, the difference was not significant. Rosie Creek beaver pond (\#25), an outlier lake with particularly high $\mathrm{CH}_{4}$ and $\mathrm{CO}_{2}$ emissions $\left(317 \mathrm{~g} \mathrm{CH}_{4}\right.$; $1138 \mathrm{~g} \mathrm{CO}_{2} \mathrm{~m}^{-2} \mathrm{yr}^{-1}$; Fig. 2), was formed prior to our study by beaver activity in an active stream system that drains into the Tanana River. The pond was subsequently influenced by thermokarst expansion (K. M. Walter Anthony, personal observation) into yedoma-type deposits, which further enhanced carbon cycling in the fluvial system.

The relationship between $\mathrm{CH}_{4}$ and $\mathrm{CO}_{2}$ emissions and other geographic parameters followed the same pattern to the extent that they were related to characteristics of yedoma and non-yedoma permafrost soils (Table 3). For instance, yedoma is characterized by eolian deposits, which among the surface geologic deposit types was also most strongly related to $\mathrm{CH}_{4}$ and $\mathrm{CO}_{2}$ emissions. Among our study lakes, yedoma lakes occurred in the interior Alaska region (Fig. 1) and tended to have a mixotrophic state, parameters that were both related to $\mathrm{CH}_{4}$ and $\mathrm{CO}_{2}$ emissions. Since the particular yedoma lakes in our study were relatively small lakes $\left(\leq 0.1 \mathrm{~km}^{2}\right)$, lake area was a morphologic parameter closely related to $\mathrm{CH}_{4}$ and $\mathrm{CO}_{2}$ emissions.

Regressions models showed that physical and chemical limnological parameters (Table 1) explained 19-63\% of deviation in the different flux pathways of $\mathrm{CH}_{4}$ emissions (Table 4). Total $\mathrm{CH}_{4}$ emission was correlated with area, SecD, SRP, and TN (Table 4). We did not find any relationships between total $\mathrm{CO}_{2}$ and the lakes' physicochemical properties, probably due to chemical equilibrium in water.

\subsection{Modes of $\mathrm{CH}_{4}$ and $\mathrm{CO}_{2}$ emission}

Total annual ebullition, consisting of direct ebullition in summer and winter as well as springtime release from IBS, was the dominant mode of $\mathrm{CH}_{4}$ emission in lakes, comprising $86 \%$ of total annual emissions from yedoma lakes and $65 \%$ from non-yedoma lakes (Table 2). Summer direct ebullition was higher in yedoma-type lakes $(26.2 \pm 15.9 \mathrm{~g}$ $\mathrm{CH}_{4} \mathrm{~m}^{-2} \mathrm{yr}^{-1}, n=6$ lakes, excluding lake \#25) than nonyedoma lakes $\left(4.0 \pm 3.7 \mathrm{~g} \mathrm{CH}_{4} \mathrm{~m}^{-2} \mathrm{yr}^{-1}, n=28\right.$ lakes $)$. This contrast drove other significant relationships in the data set: since yedoma lakes were primarily located in the interior discontinuous permafrost zone, and they dominated the mixotrophic and northern boreal forest lakes category, we found that summer ebullition was higher in interior lakes than in northern and southern lakes; summer ebullition was higher in mixotrophic lakes than in lakes of other trophic states; and northern boreal forest lakes had higher summer direct ebullition than lakes from other ecozonal categories (Tables 2 and 3). Direct ebullition of $\mathrm{CH}_{4}$ in winter and summer was correlated with lake area. Smaller lakes had higher direct ebullition (Table 4); since our yedoma study lakes were smaller than non-yedoma lakes, this factor is strongly influenced by permafrost type. The regression analysis with permafrost type categories separately (yedoma and non-yedoma lake type) creates scarce data in yedoma lakes $(n=5)$ to do this analysis. However, Spearman coefficients support this tendency, since it indicates a negative correlation with lake area among yedoma lakes (summer $r_{\mathrm{s}}=-0.66$, winter $r_{\mathrm{s}}=-0.71$ ) and in non-yedoma lakes (summer $r_{\mathrm{s}}=-0.45$, winter $\left.r_{\mathrm{s}}=-0.63\right)$.

Yedoma lakes were the only lakes in which we observed hotspot ebullition and seep densities of all seep classes were higher in yedoma lakes (mean $\pm \mathrm{SD}$ : $2.12 \pm 2.50$ A seeps $\mathrm{m}^{-2}, \quad 0.28 \pm 0.19 \mathrm{~B}$ seeps $\mathrm{m}^{-2}, \quad 0.06 \pm 0.06 \mathrm{C}$ seeps $\mathrm{m}^{-2}, 0.01 \pm 0.01$ hotspot seeps $\mathrm{m}^{-2}$ ) compared to non-yedoma lakes $\left(0.70 \pm 0.68 \mathrm{~A}_{\text {seeps }} \mathrm{m}^{-2}, 0.05 \pm 0.06\right.$ B seeps $\mathrm{m}^{-2}, \quad 0.001 \pm 0.003 \mathrm{C}$ seeps $\mathrm{m}^{-2}, 0$ hotspot seeps $\mathrm{m}^{-2}$ ). It follows that direct ebullition during the winter ice-cover period was also much higher from yedoma lakes 
Table 2. Total annual $\mathrm{CH}_{4}$ and $\mathrm{CO}_{2}$ emissions by mode from 40 lakes along a north-south latitudinal transect in Alaska. * indicates informal lake names. Eb. Sum. - direct ebullition emission to the atmosphere from seeps during the ice-free summer season; Eb. Win. - direct ebullition emission to the atmosphere from seeps during the ice-cover winter season; IBS - ice-bubble storage during spring ice melt; Stor. - storage emission following ice-out; Diff. - diffusive emission in summer; Total - total annual emissions. If there was ND (no determination) for one or more modes in a lake, then total annual emission for the lake is likely an underestimate. Average emissions are summarized at the bottom of the table, as is the percent of total annual emissions contributed by each mode as well as statistical results for differences in means among yedoma and non-yedoma lakes (Mann-Whitney test). Error terms represent standard deviation; $N$ is the individual lake number and $\mathrm{CF}$ indicates impossible determination due to lake ice completely freezing to the lake bed in winter. $\mathrm{CO}_{2}$ diffusive flux from lakes \#17 and \#18 were estimated from samples taken on multiple dates in June and July 2013 since no data were available in 2011-2012. Different letters ${ }^{\text {a,b }}$ indicate a significant difference between yedoma and non-yedoma means.

\begin{tabular}{|c|c|c|c|c|c|c|c|}
\hline \multirow[t]{2}{*}{$N$} & \multirow[t]{2}{*}{ Lake name } & \multicolumn{6}{|c|}{$\mathrm{CH}_{4}\left(\mathrm{~g} \mathrm{~m}^{-2} \mathrm{yr}^{-1}\right)$} \\
\hline & & Eb. Sum. & Eb. Win. & IBS & Diff. & Stor. & Total \\
\hline 1 & Big Sky* A31 & 0.2 & 0.0 & 0.1 & 2.0 & 2.7 & 5.0 \\
\hline 2 & Dragon's Pond* A33 & 3.0 & 0.6 & 0.6 & 3.2 & ND & 7.4 \\
\hline 3 & GTH 112 & ND & ND & ND & 2.0 & 0.0 & 2.0 \\
\hline 4 & NE2 & 2.8 & 0.5 & 0.5 & 1.3 & 0.0 & 5.1 \\
\hline 5 & E6 & 8.8 & 1.6 & 1.9 & 1.0 & ND & 13.3 \\
\hline 6 & E5 Oil Spill A30 & 0.4 & 0.1 & 0.1 & 0.9 & ND & 1.4 \\
\hline 7 & Toolik A28 & 0.6 & 0.1 & 0.1 & 0.9 & 0.2 & 2.0 \\
\hline 8 & E1 & 5.1 & 0.9 & 0.9 & 2.5 & 0.0 & 9.4 \\
\hline 9 & Autumn* A35 & 6.9 & 1.3 & 1.5 & 1.0 & ND & 10.7 \\
\hline 10 & Julieta* A27 & 7.5 & 1.3 & 1.6 & 1.9 & 0.0 & 12.3 \\
\hline 11 & El Fuego* A36 & 10.2 & 2.0 & 2.2 & ND & ND & 14.5 \\
\hline 12 & Jonas* A26 & 7.0 & 1.3 & 1.4 & ND & 0.7 & 10.4 \\
\hline 13 & Augustine Zoli* A25 & 9.3 & 1.7 & 2.3 & 4.5 & ND & 17.7 \\
\hline 14 & Ping* & 5.1 & 1.0 & 1.0 & 1.0 & 0.9 & 9.0 \\
\hline 15 & Grayling A24 & 1.9 & 0.4 & 0.6 & 2.1 & 0.0 & 5.0 \\
\hline 16 & Eugenia* & ND & ND & ND & 6.6 & 0.6 & 7.2 \\
\hline 17 & Vault* & 26.6 & 4.9 & 4.5 & 4.8 & ND & 40.9 \\
\hline 18 & Goldstream* & 13.4 & 6.7 & 2.3 & 6.0 & 1.9 & 30.3 \\
\hline 19 & Doughnut * & ND & ND & ND & 3.1 & ND & 3.1 \\
\hline 20 & Killarney* & 20.7 & 4.1 & 14.0 & 4.4 & ND & 43.3 \\
\hline 21 & Smith A13 & 2.7 & 0.3 & 0.4 & 3.2 & 0.2 & 6.7 \\
\hline 22 & Stevens Pond* & 55.0 & 12.8 & 8.1 & 3.1 & $\mathrm{CF}$ & 79.0 \\
\hline 23 & Duece A2 & 30.1 & 4.2 & 4.6 & ND & ND & 38.9 \\
\hline 24 & Ace A1 & 11.4 & 2.7 & 1.5 & ND & ND & 15.6 \\
\hline 25 & Rosie Creek* & 80.1 & 17.4 & 20.5 & 160.3 & 39.0 & 317.4 \\
\hline 26 & Monasta A37 & 4.1 & 0.3 & 0.7 & ND & ND & 5.1 \\
\hline 27 & 91 Lake* $^{*}$ & 1.5 & 0.2 & 0.2 & 2.3 & ND & 4.2 \\
\hline 28 & Otto & 2.1 & 0.2 & 0.3 & 4.9 & 0.6 & 8.1 \\
\hline 29 & Floatplane* A16 & ND & ND & ND & 1.1 & ND & 1.1 \\
\hline 30 & Nutella* A39 & 0.1 & 0.0 & 0.0 & 1.1 & ND & 1.3 \\
\hline 31 & Swampbuggy A18 & 3.2 & 0.3 & 0.4 & 0.8 & ND & 4.8 \\
\hline 32 & Montana A40 & 4.1 & 0.2 & 0.3 & 3.5 & 0.0 & 8.1 \\
\hline 33 & Rainbow Shore* A41 & 3.9 & 0.2 & 0.3 & ND & 0.9 & 5.4 \\
\hline 34 & Big Merganser A49 & 0.5 & 0.0 & 0.0 & 1.8 & 0.1 & 2.5 \\
\hline 35 & Rainbow A48 & 15.1 & 0.8 & 1.3 & ND & 0.0 & 17.2 \\
\hline 36 & Dolly Varden A47 & 2.4 & 0.1 & 0.2 & 3.2 & 0.9 & 6.8 \\
\hline 37 & Abandoned Cabin* A50 & 0.4 & 0.0 & 0.0 & ND & ND & 0.5 \\
\hline 38 & Scout A46 & ND & ND & ND & 3.6 & 0.0 & 3.6 \\
\hline 39 & Engineer A45 & 0.0 & 0.0 & 0.0 & 4.9 & 0.0 & 4.9 \\
\hline \multirow[t]{6}{*}{40} & Lower Ohmer A44 & 1.4 & 0.1 & 0.1 & 3.6 & ND & 5.3 \\
\hline & Yedoma $($ mean \pm SD) & $26.2 \pm 15.9^{\mathrm{a}}$ & $5.9 \pm 3.6^{\mathrm{a}}$ & $5.8 \pm 4.6^{\mathrm{a}}$ & $5.0 \pm 1.4^{\mathrm{a}}$ & $1.2 \pm 0.9^{\mathrm{a}}$ & $44.2 \pm 17.0^{\mathrm{a}}$ \\
\hline & Percent & $59 \%$ & $13 \%$ & $13 \%$ & $11 \%$ & $3 \%$ & $100 \%$ \\
\hline & Non-yedoma $($ mean $\pm \mathrm{SD})$ & $4.0 \pm 3.7^{b}$ & $0.6 \pm 0.6^{\mathrm{b}}$ & $0.7 \pm 0.7^{\mathrm{b}}$ & $2.4 \pm 1.3^{b}$ & $0.4 \pm 0.7^{\mathrm{a}}$ & $8.0 \pm 4.1^{b}$ \\
\hline & Percent & $50 \%$ & $7 \%$ & $9 \%$ & $30 \%$ & $5 \%$ & $100 \%$ \\
\hline & All lakes (mean $\pm \mathrm{SD})$ & & & & & $0.5 \pm 0.7$ & \\
\hline
\end{tabular}


Table 2. Continued.

\begin{tabular}{|c|c|c|c|c|c|c|}
\hline \multirow[t]{2}{*}{$N$} & \multirow[t]{2}{*}{ Lake name } & \multicolumn{5}{|c|}{$\mathrm{CO}_{2}\left(\mathrm{~g} \mathrm{~m}^{-2} \mathrm{yr}^{-1}\right)$} \\
\hline & & Eb. Sum. & Eb. Win. & Diff. & Stor. & Total \\
\hline 1 & Big Sky* A31 & 0.005 & 0.001 & 124 & 0 & 124.4 \\
\hline 2 & Dragon's Pond* A33 & 0.056 & 0.010 & 37 & ND & 37.1 \\
\hline 3 & GTH 112 & ND & ND & 42 & ND & 41.8 \\
\hline 4 & NE2 & 0.048 & 0.009 & ND & ND & 0.1 \\
\hline 5 & E6 & 0.153 & 0.028 & 36 & ND & 36.2 \\
\hline 6 & E5 Oil Spill A30 & 0.006 & 0.002 & 44 & ND & 44.3 \\
\hline 7 & Toolik A28 & 0.011 & 0.002 & 40 & ND & 40.5 \\
\hline 8 & E1 & 0.088 & 0.016 & ND & ND & 0.1 \\
\hline 9 & Autumn* A35 & 0.157 & 0.030 & 186 & ND & 186.5 \\
\hline 10 & Julieta* A27 & 0.128 & 0.023 & 270 & ND & 269.8 \\
\hline 11 & El Fuego* A36 & 0.181 & 0.036 & ND & ND & 0.2 \\
\hline 12 & Jonas* A26 & 0.122 & 0.023 & ND & 0 & 0.1 \\
\hline 13 & Augustine Zoli* A25 & 0.172 & 0.032 & 148 & 0 & 148.5 \\
\hline 14 & Ping* & 0.097 & 0.018 & 34 & 0 & 34.2 \\
\hline 15 & Grayling A24 & 0.033 & 0.007 & 40 & 0 & 39.7 \\
\hline 16 & Eugenia* & ND & ND & 131 & ND & 131.0 \\
\hline 17 & Vault* & 0.445 & 0.099 & 1278 & 0 & 1279 \\
\hline 18 & Goldstream* & 0.261 & 0.164 & 1582 & 0 & 1583 \\
\hline 19 & Doughnut $*$ & ND & ND & ND & 0 & 0.0 \\
\hline 20 & Killarney* & 0.723 & 0.070 & ND & 0 & 0.8 \\
\hline 21 & Smith A13 & 0.052 & 0.006 & 251 & 0 & 250.9 \\
\hline 22 & Stevens Pond* & 0.991 & 0.292 & 144 & $\mathrm{CF}$ & 144.9 \\
\hline 23 & Duece A2 & 0.477 & 0.087 & ND & 0 & 0.6 \\
\hline 24 & Ace A1 & 0.196 & 0.059 & ND & 0 & 0.3 \\
\hline 25 & Rosie Creek* & 1.462 & 0.404 & 1136 & ND & 1138 \\
\hline 26 & Monasta A37 & 0.076 & 0.005 & ND & ND & 0.1 \\
\hline 27 & 91 Lake* $^{*}$ & 0.029 & 0.003 & 604 & ND & 604.2 \\
\hline 28 & Otto & 0.040 & 0.004 & 234 & 0 & 233.9 \\
\hline 29 & Floatplane* A16 & ND & ND & 69 & ND & 69.5 \\
\hline 30 & Nutella* A39 & 0.002 & 0.000 & ND & ND & 0.0 \\
\hline 31 & Swampbuggy A18 & 0.056 & 0.006 & ND & ND & 0.1 \\
\hline 32 & Montana A40 & 0.076 & 0.004 & 143 & 33 & 176.4 \\
\hline 33 & Rainbow Shore* A41 & 0.075 & 0.004 & ND & 48 & 47.6 \\
\hline 34 & Big Merganser A49 & 0.010 & 0.001 & 59 & ND & 58.9 \\
\hline 35 & Rainbow A48 & 0.289 & 0.016 & 59 & ND & 59.4 \\
\hline 36 & Dolly Varden A47 & 0.047 & 0.003 & 65 & ND & 64.7 \\
\hline 37 & Abandoned Cabin* A50 & 0.008 & 0.000 & 85 & 52 & 137.5 \\
\hline 38 & Scout A46 & ND & ND & 64 & 0 & 63.9 \\
\hline 39 & Engineer A45 & 0.000 & 0.000 & 118 & 0 & 117.8 \\
\hline 40 & Lower Ohmer A44 & 0.027 & 0.001 & 157 & ND & 156.6 \\
\hline & Yedoma $($ mean $\pm \mathrm{SD})$ & $0.5 \pm 0.3^{\mathrm{a}}$ & $0.13 \pm 0.09^{\mathrm{a}}$ & $784 \pm 757^{\mathrm{a}}$ & $0^{\mathrm{a}}$ & $784 \pm 757^{\mathrm{a}}$ \\
\hline & Percent & $0.07 \%$ & $0.02 \%$ & $100 \%$ & $0 \%$ & $100 \%$ \\
\hline & Non-yedoma $($ mean $\pm \mathrm{SD})$ & $0.07 \pm 0.07^{b}$ & $0.01 \pm 0.01^{b}$ & $127 \pm 127^{b}$ & $10 \pm 20^{\mathrm{a}}$ & $137 \pm 129^{a}$ \\
\hline & Percent & $0.05 \%$ & $0.01 \%$ & $92 \%$ & $7 \%$ & $100 \%$ \\
\hline & All lakes (mean $\pm \mathrm{SD}$ ) & & & & $7 \pm 17$ & $159 \pm 322$ \\
\hline
\end{tabular}


Table 3. The Mann-Whitney and Kruskal-Wallis test results of the limnological and geographic characteristics of lakes using $\mathrm{CH}_{4}$ or $\mathrm{CO}_{2}$ emission mode as the factor. " $\neq$ " indicates a significant difference between limnological property or geographic characteristic vs. flux; " $=$ " indicates no significant difference at $Z$ value $<1.96$. IBS - ice-bubble storage; Latitude: I - interior, $\mathrm{N}$ - northern, and $\mathrm{S}$ - southern according to Sect. 2.1; permafrost soil type (Y/NY - yedoma/non-yedoma); trophic state index (TSI), ecozonal categories (EC), and deposit type (DN) according to descriptions in Table 1; maximum depth known (MD) and area (A). In the MD analysis we considered two categories: shallow lakes $\leq 2.5 \mathrm{~m}$ and deeper lakes $>2.5 \mathrm{~m}$. In the A analysis we considered two categories: small lakes $\leq 0.1 \mathrm{~km}^{2}$ and large lakes $>0.1 \mathrm{~km}{ }^{2}$.

\begin{tabular}{llllllll}
\hline Emission mode & Latitude & Y/NY & TSI & EC & DN & MD & A \\
\hline $\mathrm{CH}_{4}$ & & & & & & & \\
\hline Direct ebullition (summer) & $\mathrm{I} \neq \mathrm{N}-\mathrm{S}$ & $\neq$ & $\mathrm{O} \neq \mathrm{Mx}-\mathrm{UO}$ & $\mathrm{NBF} \neq$ ArT-SBF & $=$ & $=$ & $\neq$ \\
Direct ebullition (winter) & $\mathrm{S} \neq \mathrm{I}-\mathrm{N}$ & $\neq$ & $\mathrm{O} \neq \mathrm{Mx}-\mathrm{UO}$ & $\mathrm{SBF} \neq$ FoT-NBF & $\mathrm{E} \neq \mathrm{GMD}-\mathrm{GL}$ & $=$ & $\neq$ \\
IBS & $\mathrm{S} \neq \mathrm{I}-\mathrm{N}$ & $\neq$ & $\mathrm{O} \neq \mathrm{Mx}-\mathrm{UO}$ & $\mathrm{SBF} \neq \mathrm{FoT}-\mathrm{NBF}$ & $\mathrm{E} \neq \mathrm{GL}$ & $=$ & $\neq$ \\
Diffusion & $\mathrm{I} \neq \mathrm{N}$ & $\neq$ & $\mathrm{D} \neq \mathrm{O}-\mathrm{UO}$ & ArT $\neq$ NBF-SBF & $=$ & $=$ & $=$ \\
Storage & $=$ & $=$ & $=$ & $=$ & $=$ & $=$ & $=$ \\
Total & $\mathrm{I} \neq \mathrm{S}$ & $\neq$ & $\mathrm{O} \neq \mathrm{Mx}-\mathrm{UO}$ & $=$ & $\mathrm{GL} \neq \mathrm{E}-\mathrm{GMD}$ & $=$ & $\neq$ \\
\hline $\mathrm{CO}_{2}$ & & & & & & & \\
\hline Direct ebullition (summer) & $\mathrm{I} \neq \mathrm{N}-\mathrm{S}$ & $\neq$ & $\mathrm{O} \neq \mathrm{Mx}-\mathrm{UO}$ & $\mathrm{NBF} \neq$ ArT-SBF & $\mathrm{E} \neq \mathrm{GMD}-\mathrm{GL}$ & $=$ & $\neq$ \\
Direct ebullition (winter) & $\mathrm{S} \neq \mathrm{I}-\mathrm{N}$ & $\neq$ & $\mathrm{O} \neq \mathrm{Mx}-\mathrm{UO}$ & $\mathrm{SBF} \neq$ FoT-NBF & $\mathrm{E} \neq \mathrm{GMD}-\mathrm{GL}$ & $=$ & $\neq$ \\
Diffusion & $\mathrm{I} \neq \mathrm{N}$ & $\neq$ & $=$ & $\mathrm{NBF} \neq$ ArT-FoT-SBF & $=$ & $=$ & $\neq$ \\
Storage & $=$ & $=$ & $=$ & $=$ & $=$ & $=$ & $=$ \\
Total & $=$ & $=$ & $=$ & $=$ & $=$ & $=$ & $=$ \\
\hline
\end{tabular}

(5.9 $\pm 3.6 \mathrm{~g} \mathrm{CH}_{4} \mathrm{~m}^{-2} \mathrm{yr}^{-1}, n=6$ lakes; excluding lake \#25) than non-yedoma lakes $\left(0.6 \pm 0.6 \mathrm{~g} \mathrm{CH}_{4} \mathrm{~m}^{-2} \mathrm{yr}^{-1}, n=28\right.$ lakes) (Table 2). In contrast, ebullition was not an important mode of $\mathrm{CO}_{2}$ emission from any lakes. Total ebullition, including summer and winter direct ebullition, contributed $0.1 \%$ of the total annual $\mathrm{CO}_{2}$ emissions among all lakes (Table 2).

A comparison of $\mathrm{CH}_{4}$ composition in fresh ebullition bubbles vs. bubbles trapped by lake ice revealed that the $\mathrm{CH}_{4}$ concentration in ebullition bubbles trapped by ice was $33 \pm 12 \%$ (mean $\pm \mathrm{SD}, n=6$ lakes) lower than in ebullition bubbles escaping to the atmosphere at the lake surface unimpeded by ice (Fig. 3; Mann-Whitney $U$ test, $Z>1.96$, $p<0.05$ ).

The IBS model, which accounts for decreases in the volume and $\mathrm{CH}_{4}$ concentration of ice-trapped bubbles as their $\mathrm{CH}_{4}$ dissolves into the water column (Greene et al., 2014), revealed that IBS was on average $13 \%$ of total annual $\mathrm{CH}_{4}$ emissions from yedoma lakes $\left(5.8 \pm 4.6 \mathrm{~g} \mathrm{~m}^{-2} \mathrm{yr}^{-1}\right.$, $n=6)$ and $9 \%$ for non-yedoma lakes $\left(0.7 \pm 0.7 \mathrm{~g} \mathrm{~m}^{-2} \mathrm{yr}^{-1}\right.$, $n=28$ ) (Table 2, Fig. 2). The $\mathrm{CH}_{4}$ IBS flux from lakes was negatively correlated with area and $\mathrm{SecD}$ (Table 4). Given the minor role of $\mathrm{CO}_{2}$ direct ebullition in the annual emission budget $(<0.1 \%)$, and the even smaller role of springtime IBS, we considered IBS an insignificant mode of $\mathrm{CO}_{2}$ emission.

Storage emissions were highly variable among all lakes $\left(0.5 \pm 0.7 \mathrm{~g} \mathrm{CH}_{4} \mathrm{~m}^{-2} \mathrm{yr}^{-1}, n=20\right.$ lakes; $7 \pm 17 \mathrm{~g}$ $\mathrm{CO}_{2} \mathrm{~m}^{-2} \mathrm{yr}^{-1}, n=18$ lakes; excluding lake \#25). We did not find a significant difference in storage flux between yedoma vs. non-yedoma lakes. As with all modes of emission, lake
\#25 had the highest storage $\mathrm{CH}_{4}$ flux $\left(39.0 \mathrm{~g} \mathrm{~m}^{-2} \mathrm{yr}^{-1}\right)$. We did not find a correlation between $\mathrm{CH}_{4}$ storage flux and limnological parameters $(p<0.01)$. Since we were unable to normalize the $\mathrm{CO}_{2}$ storage flux data, it was not possible to assess potential correlations between this mode of emission and limnological parameters. In the comparison of emission modes, storage flux contributed 3 and $0 \%$ of total annual $\mathrm{CH}_{4}$ and $\mathrm{CO}_{2}$ emissions, respectively, from yedoma lakes and 5 and $7 \%$ of total annual $\mathrm{CH}_{4}$ and $\mathrm{CO}_{2}$ emissions, respectively, from non-yedoma lakes (Table 2).

$\mathrm{CH}_{4}$ diffusion emissions were statistically different between yedoma (5.0 $\pm 1.4 \mathrm{~g} \mathrm{CH}_{4} \mathrm{~m}^{-2} \mathrm{yr}^{-1}, n=5$; excluding lake \#25) and non-yedoma lakes $\left(2.4 \pm 1.3 \mathrm{~g} \mathrm{CH}_{4} \mathrm{~m}^{-2} \mathrm{yr}^{-1}\right.$, $n=26$ ). Rosie Creek beaver pond (\#25) had the highest diffusive flux (160.3 $\mathrm{g} \mathrm{CH}_{4} \mathrm{~m}^{-2} \mathrm{yr}^{-1}$ ). Diffusion comprised 11 and $30 \%$ of total annual $\mathrm{CH}_{4}$ emissions from yedoma and non-yedoma lakes, respectively. We found a significant positive correlation between $\mathrm{CH}_{4}$ diffusive flux and SRP (Table 4). In contrast, diffusion was the dominant $\mathrm{CO}_{2}$ mode of emission among all of our study lakes. Diffusion constituted 100 and $92 \%$ of $\mathrm{CO}_{2}$ emissions from yedoma and nonyedoma lakes, respectively. Diffusion from yedoma lakes $\left(784 \pm 757 \mathrm{~g} \mathrm{CO}_{2} \mathrm{~m}^{-2} \mathrm{yr}^{-1}, n=4\right.$ lakes) was significantly higher than diffusion from non-yedoma lakes $(127 \pm 127 \mathrm{~g}$ $\mathrm{CO}_{2} \mathrm{~m}^{-2} \mathrm{yr}^{-1}, n=23$ lakes). It was not possible to normalize $\mathrm{CO}_{2}$ diffusion data, so we were unable to determine potential correlations between this mode of emission and limnological parameters. 
Table 4. Single regression equations for emission modes based on data from Table 1.

\begin{tabular}{|c|c|c|c|c|c|}
\hline Flux/characteristic & Regression equation & $n$ & Adjusted $r^{2}$ & $F$ & $p$ \\
\hline \multicolumn{6}{|l|}{$\mathrm{CH}_{4}$} \\
\hline Direct ebullition (summer) & $\log \left(\mathrm{ES}-\mathrm{CH}_{4}\right)=-0.50 \log ($ area $)$ & 32 & 0.30 & 14.4919 & 0.0006 \\
\hline \multirow[t]{3}{*}{ Direct ebullition (winter) } & $\log \left(E W-\mathrm{CH}_{4}\right)=-0.93-0.68 \log ($ area $)$ & 28 & 0.60 & 43.6036 & 0.0000 \\
\hline & $\log \left(\mathrm{EW}-\mathrm{CH}_{4}\right)=0.10-1.12 \log (\mathrm{SecD})$ & 28 & 0.23 & 9.3352 & 0.0050 \\
\hline & $\log \left(\mathrm{EW}-\mathrm{CH}_{4}\right)=-2.63+0.81 \log (\mathrm{TN})$ & 24 & 0.32 & 12.4092 & 0.0018 \\
\hline \multirow[t]{2}{*}{ IBS } & $\log \left(\right.$ IBS- $\left.\mathrm{CH}_{4}\right)=-0.83-0.64 \log ($ area $)$ & 29 & 0.58 & 50.705 & 0.0001 \\
\hline & $\log \left(\mathrm{IBS}-\mathrm{CH}_{4}\right)=0.10-1.00 \log (\mathrm{SecD})$ & 29 & 0.19 & 7.9309 & 0.0088 \\
\hline Diffusion & $\log \left(\mathrm{DF}_{-} \mathrm{CH}_{4}\right)=0.55 \log (\mathrm{SRP})$ & 24 & 0.40 & 16.7767 & 0.0004 \\
\hline \multirow[t]{4}{*}{ Total } & $\log \left(\right.$ Tot $\left.-\mathrm{CH}_{4}\right)=0.43-0.37 \log ($ area $)$ & 38 & 0.27 & 15.0877 & 0.0004 \\
\hline & $\log \left(\right.$ Tot $\left.-\mathrm{CH}_{4}\right)=1.01-0.77(\mathrm{SecD})$ & 38 & 0.21 & 11.1414 & 0.0019 \\
\hline & $\log \left(\right.$ Tot- $\left.\mathrm{CH}_{4}\right)=0.42+0.55 \log (\mathrm{SRP})$ & 30 & 0.22 & 9.4969 & 0.0045 \\
\hline & $\log \left(\right.$ Tot- $\left.\mathrm{CH}_{4}\right)=0.98-0.61 \log (\mathrm{TN})$ & 32 & 0.29 & 13.7928 & 0.0008 \\
\hline \multicolumn{6}{|l|}{$\mathrm{CO}_{2}$} \\
\hline Direct ebullition (summer) & $\log \left(E S-C_{2}\right)=-1.72-0.50 \log ($ area $)$ & 32 & 0.30 & 14.6253 & 0.0006 \\
\hline \multirow[t]{2}{*}{ Direct ebullition (winter) } & $\log \left(E W-\mathrm{CO}_{2}\right)=-2.78-0.76 \log ($ area $)$ & 30 & 0.63 & 52.0960 & 0.0000 \\
\hline & $\log \left(\mathrm{EW}-\mathrm{CO}_{2}\right)=-1.83-0.76 \log (\mathrm{TN})$ & 26 & 0.24 & 9.0882 & 0.0058 \\
\hline
\end{tabular}

Table 5. Mann-Whitney and Kruskal-Wallis test results for the relationships between limnological and geographic characteristics of lakes vs. dissolved gas concentrations $\left(\mathrm{CH}_{4}\right.$ or $\left.\mathrm{O}_{2}\right)$ during winter and summer. " $\neq$ " indicates a significant difference between a geographic characteristic and flux when $Z>1.96$; "=" indicates no significant difference. Latitude: I - interior, N - northern, and S - southern according to Sect. 2.1; permafrost soil type (Y/NY - yedoma/non-yedoma); trophic state index (TSI), ecozonal categories (EC), and deposit type (DN) according to descriptions in Table 1; maximum depth known (MD) and area (A). In the MD analysis we considered two categories: shallow lakes $\leq 2.5 \mathrm{~m}$ and deeper lakes $>2.5 \mathrm{~m}$. In the A analysis we considered two categories: small lakes $\leq 0.1 \mathrm{~km}^{2}$ and large lakes $>0.1 \mathrm{~km}{ }^{2}$.

\begin{tabular}{|c|c|c|c|c|c|c|c|}
\hline Dissolved gas (season) & Latitude & $\mathrm{Y} / \mathrm{NY}$ & $\mathrm{TS}$ & $\mathrm{EC}$ & $\mathrm{DN}$ & MD & A \\
\hline $\mathrm{CH}_{4}$ (winter) & $\mathrm{I} \neq \mathrm{S}$ & $\neq$ & $\mathrm{Mx} \neq \mathrm{O}$ & $=$ & $\mathrm{E} \neq \mathrm{GL}, \mathrm{GMD}$ & $\neq$ & $\neq$ \\
\hline $\mathrm{CH}_{4}$ (summer) & $\mathrm{I} \neq \mathrm{N}, \mathrm{S}$ & $\neq$ & $\mathrm{Mx} \neq \mathrm{O}, \mathrm{UO}$ & $\mathrm{NBF} \neq \mathrm{ArT}, \mathrm{SBF}, \mathrm{FoT}$ & $\mathrm{E} \neq \mathrm{GMD}$ & $=$ & $\neq$ \\
\hline $\mathrm{O}_{2}$ (winter) & $\mathrm{I} \neq \mathrm{S}$ & $\neq$ & $\mathrm{Mx} \neq \mathrm{O}$ & $=$ & $\mathrm{E} \neq \mathrm{GL}, \mathrm{GMD}$ & $=$ & $\neq$ \\
\hline $\mathrm{O}_{2}$ (summer) & $\mathrm{I} \neq \mathrm{N}, \mathrm{S}$ & $\neq$ & $\mathrm{Mx} \neq \mathrm{O}, \mathrm{UO}$ & $\mathrm{NBF} \neq \mathrm{ArT}, \mathrm{SBF}, \mathrm{FoT}$ & $\mathrm{E} \neq \mathrm{GL}, \mathrm{GMD}$ & $=$ & $\neq$ \\
\hline
\end{tabular}

\subsection{Seasonal emissions}

Figure 4 illustrates the contribution of different gas emissions pathways to annual emissions by season. Approximately three-quarters of annual $\mathrm{CH}_{4}$ emissions were released from lakes during the open-water summer season: 71 and $79 \%$ of total annual $\mathrm{CH}_{4}$ emissions in yedoma lakes and non-yedoma lakes, respectively, were the sum of summer direct ebullition and diffusion. Spring and winter $\mathrm{CH}_{4}$ emissions were also important. From yedoma lakes, first $13 \%$ of total annual emissions occurred via IBS in spring, when the ice started to degrade; subsequently, water column storage release of dissolved gases was $3 \%$ of total annual emissions. From non-yedoma lakes, total springtime emissions were $14 \%$ of annual, consisting first of IBS (9\%) followed by storage $(5 \%)$. Wintertime emissions via direct ebullition from ice-free holes above seeps were $13 \%$ of total annual emissions from yedoma lakes and $7 \%$ from non-yedoma lakes. It is of interest to note that accounting for IBS, a newly recognized mode of emission, increased the estimate of springtime $\mathrm{CH}_{4}$ emissions based on the more commonly reported storage emission by $320 \%$.

Seasonally, $\sim 100$ and $92 \%$ of total annual $\mathrm{CO}_{2}$ emissions from yedoma and non-yedoma lakes, respectively, occurred in summer by diffusion from the open-water surface. The remaining $8 \%$ of annual emissions in non-yedoma lakes occurred in spring from water column storage flux $(7 \%)$ and winter direct ebullition $(<1 \%)$ (Table 2 and Fig. 2).

\subsection{Physical and chemical patterns}

The difference between yedoma and non-yedoma lakes was observed in several physical and chemical parameters (Ta- 


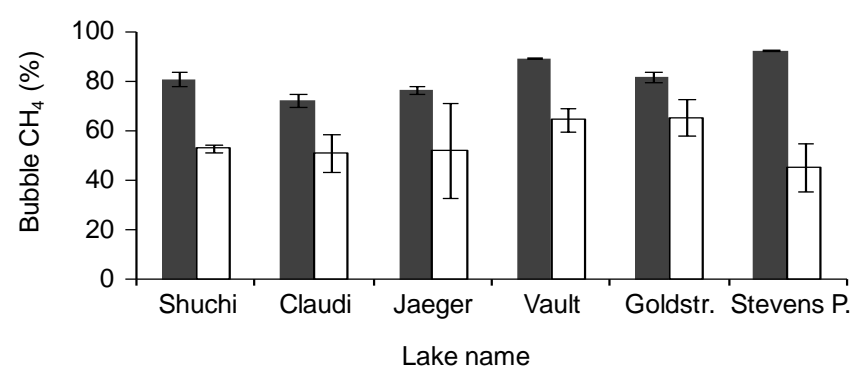

Figure 3. Average $\mathrm{CH}_{4}$ concentrations in ebullition bubbles collected at the lake surface before interaction with lake ice ("fresh bubbles", grey bars) and in ebullition bubbles trapped by the lake ice (white bars). Error bars represent standard error for $n=2$ to 41 seeps per lake. Among lakes, $\mathrm{CH}_{4}$ concentrations in icetrapped bubbles were $33 \pm 12 \%$ lower than in fresh bubbles (MannWhitney $U$ test, $Z>1.96, p<0.05)$.

bles 1, 3, and 5). Southern lakes (non-yedoma lakes) are deeper and larger than interior lakes (mostly yedoma lakes), while northern lakes (non-yedoma lakes) were not statistically different from lakes in the other regions.

Deep lakes $(>20 \mathrm{~m})$, moderately deep lakes (usually $>6 \mathrm{~m}$ ) with adequate wind protection from topography and/or vegetation, and all yedoma lakes, owing to their small surface area to volume ratios and high TOC concentrations, were thermally stratified in summer. Exceptions were two yedoma-type lakes with creeks flowing through them (Killarney Lake \#20 and Rosie Creek beaver pond \#25) and a small, shallow, yedoma thermokarst pond (Stevens Pond \#22, $1.1 \mathrm{~m}$ ) that was semi-stratified. In contrast, shallow, nonyedoma lakes (usually $<3 \mathrm{~m}$ ) and non-yedoma lakes located in mountain regions with large surface area to volume ratios and high wind conditions were well mixed.

In winter, most lakes showed inverse stratification. We found that winter bottom temperature was significantly different between northern lakes $\left(1.3 \pm 1.5^{\circ} \mathrm{C}\right)$ and southern lakes $\left(2.6 \pm 1.1^{\circ} \mathrm{C}\right)$, but none of these were significantly different from lake bottom temperature in interior Alaska $\left(1.4 \pm 1.0^{\circ} \mathrm{C}\right)$, which is mainly due to the contrasting climatic conditions and the relatively shallow depths of northern lakes compared to southern lakes.

In most lakes, if there was a dissolved $\mathrm{O}_{2}$ (DO) gradient, then DO was highest near the lake surface and decreased with depth in winter and summer. Three exceptions were El Fuego Lake (\#11), 91 Lake (\#27), and Dolly Varden Lake (\#36), where we observed an increase in DO with depth in summer, likely due to benthic photosynthesis in the shallow lakes (\#11 and \#27) and a deep chlorophyll maximum (DCM) in the deep lake (\#36). In \#36 we observed Chl $a$ concentrations near the surface of $\sim 3.7 \mu \mathrm{g} \mathrm{L}^{-1}$; Chl $a$ concentrations increased with depth to a maximum $(23.0 \mu \mathrm{g} \mathrm{L}-1)$ just below $20 \mathrm{~m}$. DCM is a common trend in deep, clearwater lakes with low trophic state (Gervais et al., 1997; Camacho, 2006). Among yedoma lakes, lake-bottom dissolved
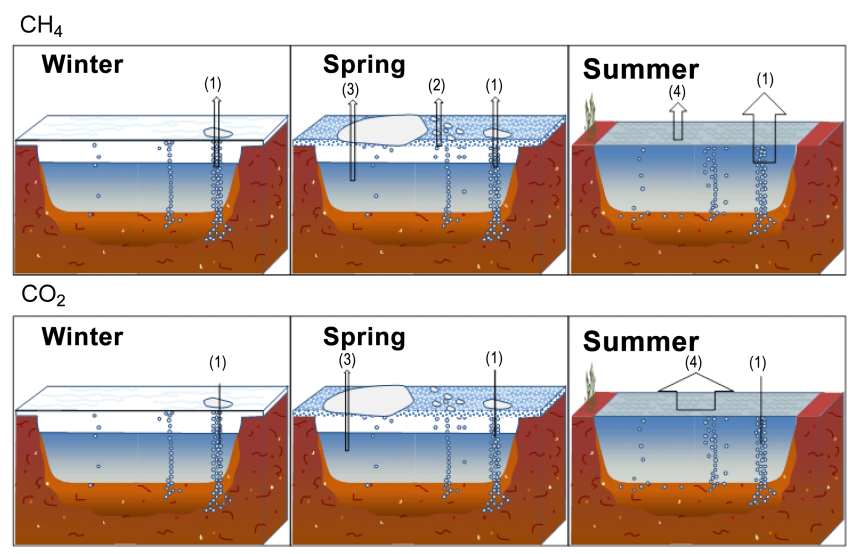

Figure 4. Illustration of $\mathrm{CH}_{4}$ and $\mathrm{CO}_{2}$ emissions pathways during different seasons in Alaskan lakes. The thickness of arrows indicates the relative magnitude of contribution from each pathway according to Table 2: (1) direct ebullition through ice-free hotspot seeps in winter and from all seep classes during the last month of ice cover in spring and in summer, (2) ice-bubble storage (IBS) emission during spring ice melt, (3) storage emission of dissolved gases accumulated under lake ice when ice melts in spring, and (4) diffusion emission from open water in summer.

oxygen (DO) concentrations were $<0.1 \mathrm{mg} \mathrm{L}^{-1}$ in both winter and summer. In contrast, $81 \%$ of the 32 non-yedoma lakes had well-oxygenated lake bottoms in summer; the lakebottom water DO concentration in the other $19 \%$ of lakes was $<0.1 \mathrm{mg} \mathrm{L}^{-1}$. In winter, we observed the reverse pattern among non-yedoma lakes: $76 \%$ of 17 non-yedoma lakes measured had lake-bottom DO $<0.1 \mathrm{mg} \mathrm{L}^{-1}$, while $24 \%$ of non-yedoma lakes, all of which were southern lakes, had well-oxygenated lake bottoms in winter. All temperature and DO profiles measured on the study lakes are shown in Supplement Fig. S1.

DO concentrations were inversely related to dissolved $\mathrm{CH}_{4}$ concentrations in the lake bottom water during winter and summer (Fig. 5). This relationship suggests a strong influence by microbial processes that consume $\mathrm{O}_{2}$, consequently reducing aerobic oxidation of dissolved $\mathrm{CH}_{4}$, particularly in the organic-rich, yedoma lakes of interior Alaska (Table 5 and Sect. 4.3). Additionally, we found significant statistical relationships between lake area and dissolved gas concentrations $\left(\mathrm{CH}_{4}\right.$ and $\left.\mathrm{O}_{2}\right)$ among our yedoma (small lakes) and non-yedoma study lakes (generally larger lakes) (Table 5).

Five additional limnological parameters also showed significant differences between yedoma and non-yedoma lakes (Table 1). The TOC, SRP, TN, Chl $a$, and SecD indicated higher nutrient availability and higher primary production in the mixotrophic, yedoma lakes and/or their watersheds (Table 1). ORP values were significantly different between winter and summer in all lakes (Table 1), but were more than 2.5 and 1.5 times lower in yedoma lakes compared to 


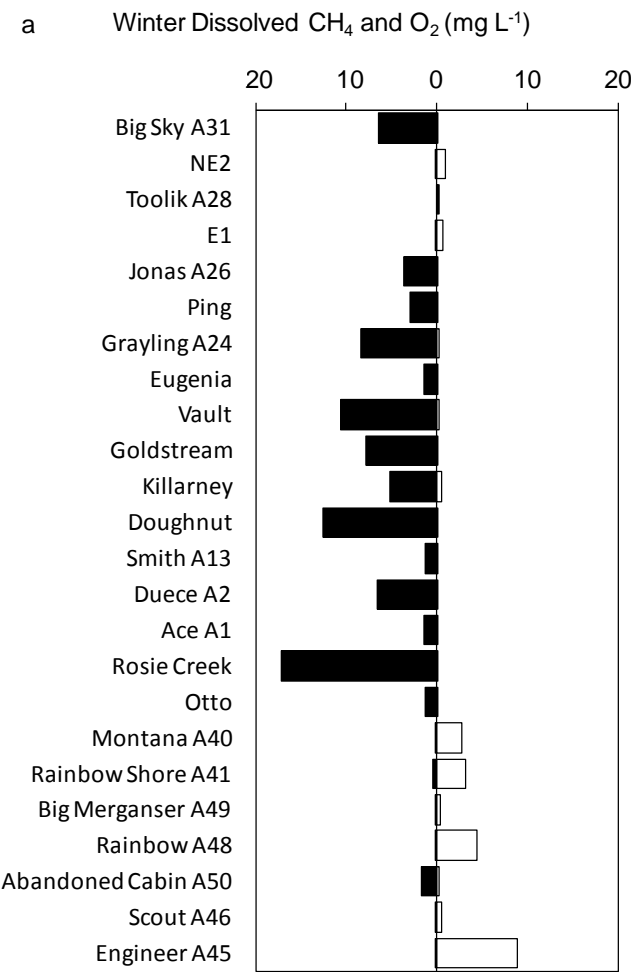

b

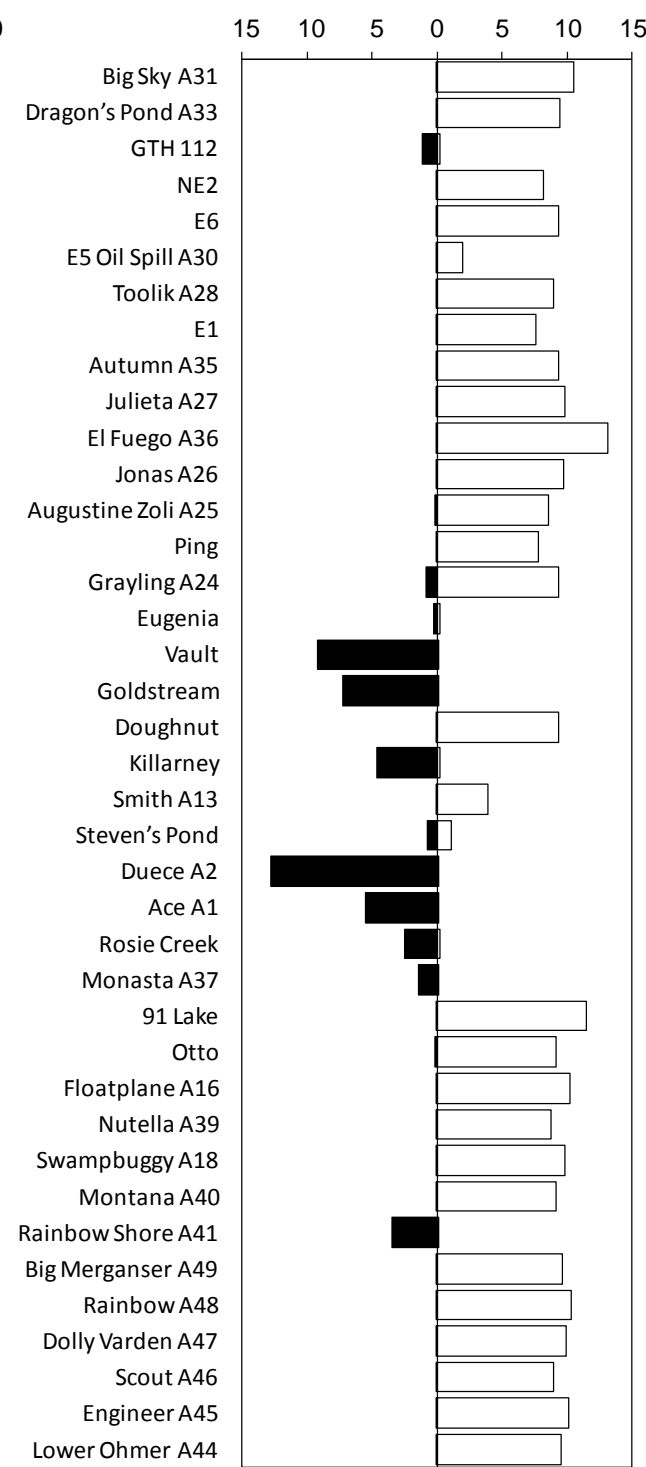

Figure 5. Average dissolved $\mathrm{CH}_{4}$ (black bars) and $\mathrm{O}_{2}$ (white bars) concentrations in lake bottom water during winter (a) and summer (b). Yedoma lakes are indicated by "Y". In winter, a Spearman coefficient of $r_{\mathrm{s}}=0.58$ indicates a moderate positive correlation between dissolved $\mathrm{CH}_{4}$ and $\mathrm{O}_{2}$; in summer $r_{\mathrm{s}}=0.70$ indicates a strong positive correlation.

non-yedoma lakes in winter and summer, respectively, indicating greater reducing conditions in yedoma-lake water columns. Temperature and $\mathrm{pH}$ were significantly different between summer and winter in non-yedoma lakes, while only temperature differed seasonally in yedoma lakes. Altogether, these findings of higher primary production and lower ORP are consistent with the observations of high $\mathrm{CH}_{4}$ and low $\mathrm{O}_{2}$ concentrations in yedoma lakes compared to non-yedoma lakes (Fig. 5).

\section{Discussion}

\subsection{Emission modes}

The relative magnitude of different emission modes in this study followed the same general pattern observed previously (Casper et al., 2000; Bastviken et al., 2004; Abril et al., 2005; Repo et al., 2007), with ebullition dominating lake $\mathrm{CH}_{4}$ emissions and diffusion dominating $\mathrm{CO}_{2}$ emissions. Most studies of ebullition are conducted by distributing bubble traps in lakes without prior knowledge of discrete seep locations. Since seep locations are identified in winter as vertical stacks of bubbles in lake ice that represent repeated ebul- 
a

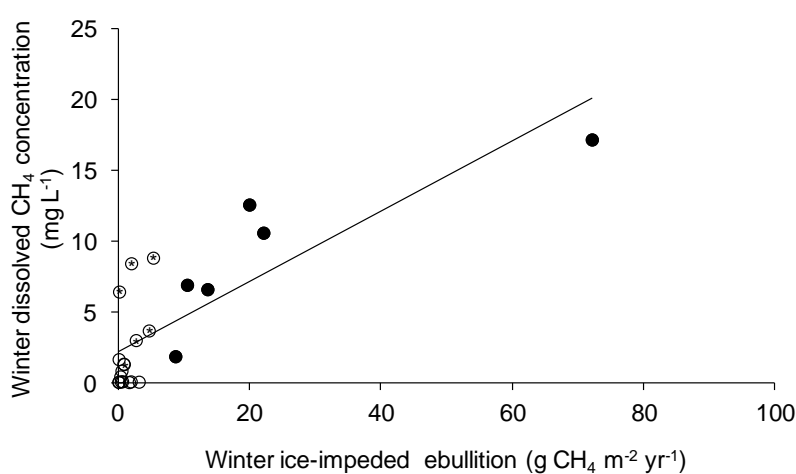

b

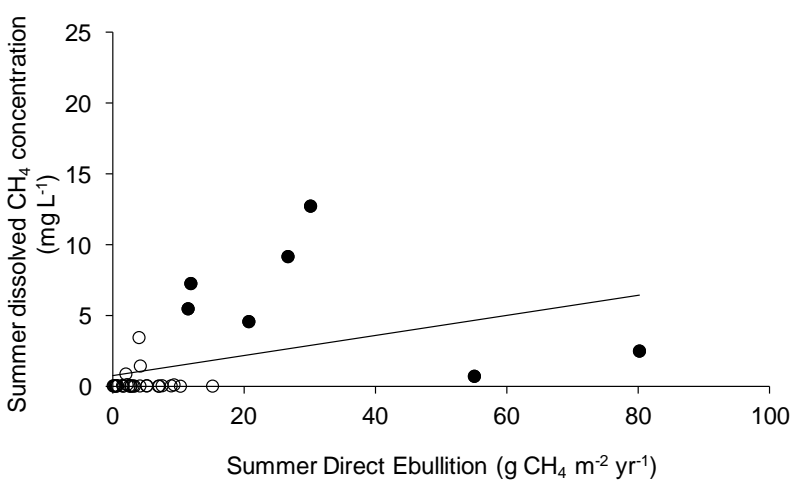

Figure 6. Dissolved $\mathrm{CH}_{4}$ concentrations measured in lake bottom water vs. winter ice-impeded ebullition in winter (a) and direct ebullition in summer (b). The Spearman coefficients, $r_{\mathrm{S}}=0.72$ and $r_{\mathrm{s}}=0.42$, indicate a strong positive correlation and a weak positive correlation in winter and summer, respectively. All lakes were considered a single population; however, yedoma lakes (closed circles) had higher concentrations of lake-bottom dissolved $\mathrm{CH}_{4}$ (mean \pm SD: $9.3 \pm 5.4$ winter, $6.7 \pm 4.1 \mathrm{mg} \mathrm{L}^{-1}$ summer) and a higher density of ebullition seeps (Sect. 3.2) than non-yedoma lakes (open circles; $2.1 \pm 3.0$ winter, $0.3 \pm 0.7 \mathrm{mg} \mathrm{L}^{-1}$ summer). We observed relatively high concentrations of dissolved $\mathrm{CH}_{4}$ in some nonyedoma lakes in winter due to dissolved gas exclusion during ice formation in shallow lakes that nearly froze to the lake bed, indicated by " $*$ ". Excluding lakes that nearly froze to the lake bed, the mean dissolved $\mathrm{CH}_{4}$ in the remaining non-yedoma lakes was $0.3 \pm 0.5 \mathrm{mg} \mathrm{L}^{-1}$ in winter.

lition from discrete point sources, surveys of lake-ice bubbles reveal the locations and densities of ebullition seeps on lakes. Surveys also show the relative proportion of (ebullition) bubble-free black ice, which in nearly all ice-covered lakes dominates on an area basis. Walter et al. (2006) identified non-point-source bubbling from the seep-free fraction of the lake as "background ebullition". Background ebullition is thought to originate primarily from methanogenesis in surface lake sediments in summer; in contrast, ebullition seeps consist of bubble tubes that allow $\mathrm{CH}_{4}$ produced at depth in sediments to migrate efficiently as bubbles to the sediment surface in summer and winter by the repeated release from point-source locations. Bubble traps placed in seep and non-seep locations and monitored year-round in two Siberian lakes showed that seep ebullition dominated total annual $\mathrm{CH}_{4}$ emissions. Background ebullition was high in summer, nearly absent in winter, and altogether comprised $\sim 25 \%$ of total annual $\mathrm{CH}_{4}$ emissions in the Siberian lakes. Preliminary results from bubble traps placed in some of our Alaskan study lakes in locations where no seep ebullition bubbles were observed in winter also showed high summertime bubbling (K. M. Walter Anthony, unpublished data, 2014). This suggests that background ebullition occurs in Alaska too. Since our estimate of lake ebullition in the Alaskan lakes is based solely on discrete seeps and does not include nonseep background ebullition, we consider that our estimate of total lake ebullition is below the total actual ebullition flux. Given that methanogenesis is highly temperature dependent (Dunfield et al., 1993; Schulz et al., 1997; Duc et al., 2010; Marotta et al. 2014; Yvon-Durocher et al. 2014) and that surface lake sediments heat up in summer, accounting for background ebullition would likely increase the total ebullition emissions from all of the Alaskan study lakes.

The ice-bubble storage (IBS) mode of emission described here is a newly recognized $\mathrm{CH}_{4}$ ebullition flux component in lakes (Greene et al., 2014) that has not previously been included in regional studies. Given the coarse temporal resolution of temperature and dissolved gas data used as input to the IBS model, we acknowledge that our estimate of IBS is a first-order approximation. However, strong agreement in the relative importance of IBS in the annual $\mathrm{CH}_{4}$ budget of Goldstream Lake (\#18) in this study using coarse-resolution data (IBS $6 \%$ of total annual $\mathrm{CH}_{4}$ emission) vs. the estimate from Greene et al. (2014) using highly detailed field data allowing detailed modeling (IBS was 6 and $9 \%$ of total annual emissions in two different years) suggests that our firstorder approximations of IBS may be valid. Since IBS was an important mode of $\mathrm{CH}_{4}$ emissions among our study lakes (13 and $9 \%$ of total annual emissions in yedoma and nonyedoma lakes, respectively), it is likely that past estimates of the magnitude and seasonality of $\mathrm{CH}_{4}$ emissions from lakes with ebullition seeps were incomplete. Greene et al. (2014) found that a large fraction $(\sim 80 \%)$ of $\mathrm{CH}_{4}$ diffused from ebullition bubbles trapped under lake ice into the lake water in Goldstream Lake. Coarser-resolution modeling of the IBS process for our study lakes also suggested that approximately $80 \%$ of $\mathrm{CH}_{4}$ dissolved out of ice-trapped bubbles. The mean and standard deviation of the $\mathrm{CH}_{4}$ fraction dissolving out of ice-trapped bubbles was $83 \pm 0.9 \%$ for 34 lakes (range 65-89\% for 33 lakes, excluding Killarney Lake with anomalously low $\mathrm{CH}_{4}$ content in bubbles freshly released from sediments). Detailed measurements and modeling in Goldstream Lake showed that about half of this redissolved $\mathrm{CH}_{4}$ was ultimately oxidized (Greene et al., 2014). Due to a paucity of field data, we did not model $\mathrm{CH}_{4}$ oxidation; however, given the observed $\mathrm{CH}_{4}$ oxidation potentials in our study lakes through incubation studies (Martinez-Cruz et al., 2015), it is likely that some fraction of the redissolved ebullition bub- 
bles is oxidized. The unoxidized fraction of dissolved $\mathrm{CH}_{4}$ is subject to release to the atmosphere via water column convection and diffusion as storage emissions in spring when ice more completely disintegrates and as diffusion during summer (Greene et al., 2014). Thus the storage and diffusion modes of emission may involve not only dissolved $\mathrm{CH}_{4}$ that diffused out of lake sediments but also dissolved $\mathrm{CH}_{4}$ that first originated as ebullition bubbles prior to ice entrapment. Since ebullition seeps were important components of wholelake $\mathrm{CH}_{4}$ emissions in all of our study lakes, as well as in tens of other lakes previously reported in Alaska (Walter Anthony et al., 2012) and Siberia (Walter et al., 2006; Walter Anthony et al., 2010), IBS should be studied and accounted for in global lake $\mathrm{CH}_{4}$ emission budgets.

Lake $\mathrm{CH}_{4}$ storage emission estimates for our Alaska study lakes ( $0.5 \pm 0.7 \mathrm{~g} \mathrm{CH}_{4} \mathrm{~m}^{-2} \mathrm{yr}^{-1}$; Table 2$)$, which comprised $\sim 4 \%$ of total annual emissions, were highly variable and on the same order of magnitude as the mean estimate for other northern lakes reported by Bastviken et al. (2004) (2.4 $\left.\mathrm{g} \mathrm{CH}_{4} \mathrm{~m}^{-2} \mathrm{yr}^{-1}\right)$ and Bastviken et al. (2011) (0.8 $\mathrm{g}$ $\mathrm{CH}_{4} \mathrm{~m}^{-2} \mathrm{yr}^{-1}$; pan-Arctic). Storage emissions from global lakes ranged from $<0.1$ to $37 \mathrm{~g} \mathrm{CH}_{4} \mathrm{~m}^{-2} \mathrm{yr}^{-1}$, comprising 0.5 to $81 \%$ of the total annual emissions (Bastviken et al., 2011). This also suggests high variability in this emission mode among global lakes. The large relative error for storage flux measured among our Alaska study lakes (140\%; mean $\pm \mathrm{SD}, 0.5 \pm 0.7 \mathrm{~g} \mathrm{CH}_{4} \mathrm{~m}^{-2} \mathrm{yr}^{-1}$ ) confirms that there is large variability associated with this mode of emission; however, $\mathrm{CH}_{4}$ storage emissions in our Alaska study lakes were $<2.7 \mathrm{~g} \mathrm{CH}_{4} \mathrm{~m}^{-2} \mathrm{yr}^{-1}$, except in Rosie Creek beaver pond $\left(\# 25,39 \mathrm{~g} \mathrm{CH}_{4} \mathrm{~m}^{-2} \mathrm{yr}^{-1}\right)$. The small sample size $(n=2$ yedoma lakes) might lead to potential bias in the storage emissions for yedoma vs. non-yedoma lakes. Further analyses are required to address the differences in storage emissions between these lake types. Additionally, full or partial turnover of the lake water column in fall can release additional stored $\mathrm{CH}_{4}$ (Bastviken et al., 2004; Bellido et al., 2009). We acknowledge that our storage values for $\mathrm{CH}_{4}$ and $\mathrm{CO}_{2}$ are gross estimations since we estimated only spring storage emission and did not take into account potential additional emissions associated with fall turnover or the impacts of lake morphology. Low spatiotemporal resolution sampling to calculate storage emissions also introduces imprecision in our estimates. A better method would involve continuous measurements of dissolved $\mathrm{CH}_{4}$ and $\mathrm{CO}_{2}$, temperature, and $\mathrm{pH}$ in lake water column at multiple locations in the lake throughout the full ice-melt period.

\subsection{Geographic patterns of lake $\mathrm{CH}_{4}$ and $\mathrm{CO}_{2}$ emissions in Alaska}

Previous regional analyses of northern lake emissions found a relationship between $\mathrm{CH}_{4}$ emissions from lakes and latitude that was explained by temperature (Marotta et al., 2014; Rasilo et al., 2015; Yvon-Durocher et al., 2014). Pri- mary production in warmer climates may supply more organic substrate for methanogenesis (Duc et al., 2010; OrtizLlorente and Alvarez-Cobelas, 2012; Marotta et al., 2014), and methanogenesis is physiologically sensitive to temperature (Schulz et al., 1997; Yvon-Durocher et al., 2014). However, the lakes in these studies were not permafrost-affected. In our north-south Alaska transect we did not find a relationship between any pathway of lake $\mathrm{CH}_{4}$ emissions and latitude or temperature. We attribute this finding to the presence and geographic diversity of permafrost types (yedoma vs. non-yedoma) (Jorgenson et al., 2008; Kanevskiy et al., 2011), which is more a function of periglacial history and topography in Alaska than it is of latitude or recent climate. While methanogenesis in surface sediments of lakes globally is fueled by contemporary autochthonous primary production and allochthonous organic matter supply (processes typically controlled by latitude and climate in undisturbed systems), thermokarst-influenced lakes have an additional, deeper source of organic matter that fuels methanogenesis: thawing permafrost in the thaw bulbs beneath lakes and along thermally eroding shorelines. Organic matter supplied by thawing permafrost, particularly in lakes formed in thick, organic-rich, yedoma-type deposits, can supply more substrate to methanogenesis than the more contemporary organic carbon substrates supplied to surface lake sediments (Kessler et al., 2012).

The interior Alaska yedoma lakes, which had the highest $\mathrm{CH}_{4}$ and $\mathrm{CO}_{2}$ emissions, are largely thermokarst lakes formed by thaw of organic-rich yedoma permafrost. Radiocarbon ages (18-33 kyr BP) and $\delta \mathrm{Mx}$-depleted values of $\mathrm{CH}_{4}$ in ebullition bubbles collected from the interior Alaskan thermokarst lakes suggested that thaw of late Pleistocene yedoma organic matter fuels methanogenesis in these lakes (Walter et al., 2008; Brosius et al., 2012). The 6-fold difference in $\mathrm{CH}_{4}$ emissions between yedoma lakes and nonyedoma lakes throughout the rest of Alaska is likely explained by the variability in the availability of recently thawed permafrost organic matter, which provides a larger additional substrate for methanogenesis in the yedoma lakes owing to the thickness (usually tens of meters) of organicrich yedoma deposits (Kanevskiy et al., 2011; Walter Anthony et al., 2012).

Previous research using stable isotopes and radiocarbon dating of $\mathrm{CH}_{4}$ in ebullition bubbles in yedoma lakes demonstrated that stronger ebullition seeps originate from greater depths beneath the sediment interface and are characterized by older ${ }^{14} \mathrm{C}$ ages and more depleted $\delta D$ values associated with thaw of Pleistocene-aged yedoma permafrost (Walter et al., 2008). The disproportionately large contribution of strong hotspot ebullition seeps to emissions from yedoma lakes (mean \pm SD: $17 \pm 12 \%$ of total annual emissions) in this study suggests microbial production of $\mathrm{CH}_{4}$ at greater depths in sediments beneath yedoma lakes. In contrast, the absence of hotspot ebullition seeps in non-yedoma lakes, which we observed to also have dense sediments, suggests 
that $\mathrm{CH}_{4}$ formation by microbial decomposition of organic matter is more restricted to shallower sediment depths in the non-yedoma lakes. This is consistent with maps of permafrost soil organic carbon distributions, whereby the organic horizons of non-yedoma permafrost soils are typically thinner than yedoma deposits (Ping et al., 2008; Tarnocai et al., 2009; Kanevskiy et al., 2011).

The relationship between ebullition, dissolved $\mathrm{CH}_{4}$ concentration, and lake type (Fig. 6) also indicates that ebullition seeps releasing $\mathrm{CH}_{4}$ produced deep in thaw bulbs contribute more to $\mathrm{CH}_{4}$ cycling in yedoma lakes than in nonyedoma lakes. Yedoma lakes, which had a higher density of ebullition seeps than non-yedoma lakes (Sect. 3.2), had both higher volumes of $\mathrm{CH}_{4}$-rich bubbles impeded by lake ice and higher concentrations of dissolved $\mathrm{CH}_{4}$ in the lake water in winter (Fig. 6a, $r_{\mathrm{s}}=0.72$ ). Based on Greene et al. (2014), in which $93 \%$ of dissolved $\mathrm{CH}_{4}$ in the water column in winter originated from $\mathrm{CH}_{4}$ dissolution from ebullition bubbles trapped by lake ice, we attribute the higher concentrations of dissolved $\mathrm{CH}_{4}$ in the yedoma study lakes to the process of $\mathrm{CH}_{4}$ dissolution from ice-trapped bubbles. Modeling results, which showed that approximately $80 \%$ of $\mathrm{CH}_{4}$ in bubbles trapped by lake ice in our study lakes dissolved into the water column, support this conclusion. Other important processes that would also control dissolved $\mathrm{CH}_{4}$ concentrations in lake water are diffusion from sediments and $\mathrm{CH}_{4}$ oxidation. Given the thicker $\mathrm{CH}_{4}$-producing sediment package beneath yedoma lakes, we would expect diffusion of dissolved $\mathrm{CH}_{4}$ from yedoma lakes to be higher than that of non-yedoma lakes. Ex situ incubations by Martinez-Cruz et al. (2015) on a subset of our Alaska study lakes also showed that yedoma lakes had higher $\mathrm{CH}_{4}$ oxidation potentials, owing in large part to higher concentrations of the dissolved $\mathrm{CH}_{4}$ substrate in these lakes. Compared to winter, the weaker correlation between dissolved $\mathrm{CH}_{4}$ and direct ebullition in summer (Fig. 6b, $r_{\mathrm{s}}=0.42$ ) has several potential explanations. First, in summer, ebullition bubbles escape directly to the atmosphere, so the dissolved $\mathrm{CH}_{4}$ stock of the water column is not supplied from ice-trapped bubble dissolution like it is in winter unless residual winter-dissolved bubble $\mathrm{CH}_{4}$ remains in the water column in summer. Second, dissolved $\mathrm{CH}_{4}$ diffusing from lake sediments in summer may be more immediately oxidized by aerobic $\mathrm{CH}_{4}$ consumption since $\mathrm{O}_{2}$ is more available in lake water from atmospheric diffusion and autochthonous primary production. Finally, higher SRP, $\mathrm{TN}$, and Chl $a$ concentrations in yedoma lakes (Table 1) suggests primary production in yedoma lakes may contribute relatively more substrate to methanogenesis in surface sediments. $\mathrm{CH}_{4}$ produced in surface sediments more readily escapes to the water column via diffusion than $\mathrm{CH}_{4}$ produced in thaw bulbs, which preferentially escapes by ebullition (Tan et al., 2014). Higher diffusion from surface sediments would support higher concentrations of dissolved $\mathrm{CH}_{4}$ in lake water, a process that can be independent of ebullition from thaw bulbs in summer. This explanation is supported by 2 times higher summer diffusion emissions from yedoma lakes compared to non-yedoma lakes (Table 2), despite higher observed $\mathrm{CH}_{4}$ oxidation potentials in yedoma lakes vs. non-yedoma lakes (Martinez-Cruz et al., 2015).

$\mathrm{CO}_{2}$ diffusion, which was $\sim 100$ and $92 \%$ of total annual $\mathrm{CO}_{2}$ emissions from yedoma and non-yedoma lakes, respectively, was 6 times higher on average in yedoma lakes than in non-yedoma lakes. Potential explanations include enhanced $\mathrm{CO}_{2}$ production associated with yedoma organic matter decomposition, photooxidation of the large DOC pool observed in the mixotrophic yedoma lakes, and potentially higher rates of $\mathrm{CH}_{4}$ oxidation in yedoma lakes (Martinez-Cruz et al., 2015) generating more $\mathrm{CO}_{2}$ in the lake water columns. The higher DOC content of yedoma lakes would favor $\mathrm{CO}_{2}$ production; however, DOC quality has also been observed to be an important control over $\mathrm{CO}_{2}$ emissions from northern lakes (Kortelainen et al., 2006). Vonk et al. (2013) recently showed that Pleistocene-aged DOC mobilized in stream water draining yedoma outcrops is exceptionally biolabile among contemporary fluvial systems in the Arctic. This suggests that yedoma-derived DOC in lakes may be more easily decomposed than non-yedoma DOC. Finally, possible differences in watershed sizes draining into lakes could also influence $\mathrm{CO}_{2}$ concentrations in lakes and diffusion emissions since terrestrial dissolved inorganic carbon often dominates lake $\mathrm{CO}_{2}$ pools (Kling et al., 1992; Battin et al., 2009; Tranvik et al., 2009). While Kortelainen et al. (2013) found lake water $\mathrm{NO}_{3}^{-}$concentrations in Finnish lakes to control the ratio of terrestrially derived $\mathrm{CO}_{2}$ emissions from lakes versus long-term carbon sequestration in lake sediments, we found no relationship between $\mathrm{CO}_{2}$ emissions and $\mathrm{NO}_{3}^{-}$concentrations. Since we did not study long-term carbon sequestration or the other aforementioned processes, and since our calculations contain uncertainty associated with the assumption that single-day measurements of dissolved $\mathrm{CO}_{2}$ and $\mathrm{CH}_{4}$ in lakes represent the mean flux for the entire open-water period, further research is needed to validate these hypotheses in the Alaskan lakes.

\subsection{Dissolved $\mathrm{CH}_{4}$ and $\mathrm{O}_{2}$ dynamics}

Dissolved $\mathrm{O}_{2}$ concentration is a useful parameter for predicting the $\mathrm{CH}_{4}$ concentrations in Alaskan lakes. The inverse relationship observed between $\mathrm{CH}_{4}$ and $\mathrm{O}_{2}$ concentration in lake water (Fig. 5) suggests physical and biological processes govern the availability of these compounds to different degrees in various lakes.

There are several possible explanations for the pattern of seasonally higher dissolved $\mathrm{CH}_{4}$ and lower $\mathrm{O}_{2}$ concentrations in winter among lakes (Fig. 5): (1) ice cover inhibits $\mathrm{O}_{2}$ transfer from the atmosphere into the water column (White et al., 2008); (2) primary production in lakes declines as day length shortens (White et al., 2008; Clilverd et al., 2009); (3) snow cover impedes light transfer, further extinguishing photosynthesis beneath the ice (Welch et al., 1987; Clilverd et 
al., 2009); and, finally, (4) aerobic microorganisms consume residual $\mathrm{O}_{2}$ in the water beneath the ice (Bellido et al., 2009; Clilverd et al., 2009). The resulting anoxic conditions facilitate anaerobic processes like methanogenesis and decrease methanotrophy (Dunfield et al., 1993). All the while, $\mathrm{CH}_{4}$ is emitted from lake sediments throughout winter via diffusion and seep ebullition. Many ebullition bubbles are impeded by lake ice, leading to dissolution of $\mathrm{CH}_{4}$ from bubbles and an increase in dissolved $\mathrm{CH}_{4}$ concentration. In summer, the lack of ice cover allows $\mathrm{CH}_{4}$ in bubbles to be released directly to the atmosphere without partially dissolving in the lake water column. This explains in part the lower $\mathrm{CH}_{4}$ concentrations in lake water in summer (Greene et al., 2014). Furthermore, the $\mathrm{O}_{2}$ concentration in lake water increases in summer by gas exchange with the atmosphere and by primary production in lakes (Fig. 5b). As a result, a fraction of dissolved $\mathrm{CH}_{4}$ in lake water is emitted to the atmosphere, while methanotrophic activity, supported by elevated $\mathrm{O}_{2}$ concentration, oxidizes another fraction (Martinez-Cruz et al., 2015).

In addition to the seasonal variations described above, a permafrost-type effect on dissolved $\mathrm{CH}_{4}$ and $\mathrm{O}_{2}$ patterns was also observed. While most of the non-yedoma lakes were well oxygenated during summer, yedoma lakes in interior Alaska had contrastingly lower $\mathrm{O}_{2}$ concentrations and higher dissolved $\mathrm{CH}_{4}$ concentrations beneath the thermocline. This suggests high methanogenic activity in sediments that fuels $\mathrm{CH}_{4}$ oxidation in the water column. Aerobic methane oxidation together with other aerobic processes reduces $\mathrm{O}_{2}$ concentration under the thermocline, where stratification limits $\mathrm{O}_{2}$ ingress from superficial water layers.

Understanding the dynamics of dissolved $\mathrm{CH}_{4}$ and $\mathrm{O}_{2}$ in northern lakes also has relevance to the distribution of lake biota. Ohman et al. (2006) showed that $\mathrm{CH}_{4}$ concentration in the water column is correlated with fish community composition in lakes, which is easily understood since $\mathrm{CH}_{4}$ can be used as an indicator of anoxia and therefore correlated with the fish $\mathrm{O}_{2}$ requirements.

\subsection{Limnological and morphological patterns}

Single linear regression analysis indicated that the best limnological predictors of $\mathrm{CH}_{4}$ emissions in the Alaskan lakes were area, SecD, SRP, and TN, all of which are indicators of lake metabolism and morphology (Table 4). These findings are consistent with the patterns that explain lake $\mathrm{CH}_{4}$ emissions in Michigan, Canada, Sweden, and Finland (Bastviken et al., 2004; Juutinen et al., 2009; Rasilo et al., 2015), suggesting that lake trophic state and organic matter quality, rather than carbon concentration alone, might play prevailing roles in $\mathrm{CH}_{4}$ and $\mathrm{CO}_{2}$ production and fluxes. The association between high $\mathrm{CH}_{4}$ emissions and high nutrients and Chl $a$ concentrations among yedoma lakes compared to nonyedoma lakes is consistent with the geographic patterns previously observed in Siberian lakes. Higher aquatic production observed in Siberian yedoma lakes compared to non- yedoma lakes in the same climate zone was attributed to fertilization of the yedoma lakes by nitrogen- and phosphorusrich thawing yedoma permafrost (Walter Anthony et al., 2014). Positive relationships between lake nutrient status and $\mathrm{CH}_{4}$ fluxes together with low or negative $\mathrm{CO}_{2}$ fluxes observed in other northern lakes also suggested that lake trophy plays diverging roles in $\mathrm{CH}_{4}$ and $\mathrm{CO}_{2}$ fluxes (Del Giorgio et al., 1999; Lapierre and Del Giorgio, 2012). Nutrients can increase primary productivity that simultaneously fuels methanogenesis and draws down dissolved $\mathrm{CO}_{2}$.

The negative correlation between $\mathrm{CH}_{4}$ emissions and lake area indicates that small lakes had higher total annual $\mathrm{CH}_{4}$ emissions. This finding is driven by yedoma lakes, which were on average much smaller and tended to develop more noticeable anaerobic hypolimnia than non-yedoma lakes (Table 1, Fig. 5; Supplement Fig. B). This finding is also consistent with lake $\mathrm{CH}_{4}$ emission patterns in other regions whereby smaller lakes have higher $\mathrm{CH}_{4}$ emissions due to a stronger relative contribution of littoral organic matter to whole-lake methanogenesis (Bastviken et al., 2004; Juutinen et al., 2009; Rasilo et al., 2015).

\subsection{Climate warming impacts of Alaskan lake emissions}

Previously, Kling et al. (1992) showed that tundra lakes near Toolik Field station emit $\mathrm{CH}_{4}$ and $\mathrm{CO}_{2}$ via diffusion. More recently, Walter Anthony et al. (2012) recognized the importance of $\mathrm{CH}_{4}$ ebullition from ecological seeps (formed from recent microbial decomposition vs. geologic seeps releasing fossil $\left.\mathrm{CH}_{4}\right)$ in Alaskan lakes $\left(0.75 \mathrm{Tg} \mathrm{CH}_{4} \mathrm{yr}^{-1}\right)$; however, this represented the quantity of ebullition seep $\mathrm{CH}_{4}$ released from sediments rather than the magnitude of atmospheric emissions. Since ebullition emission is partially impeded by lake ice in winter, and a fraction of $\mathrm{CH}_{4}$ dissolved out of bubbles beneath ice is oxidized by microbes (Greene et al., 2014), ebullition emissions to the atmosphere are lower than what is released annually from sediments. This study is the first to consider multiple modes of emissions for $\mathrm{CO}_{2}$ and $\mathrm{CH}_{4}$ together, including the ice-bubble storage process, for a large number of Alaskan lakes spanning large geographic gradients. Scaling total annual $\mathrm{CH}_{4}$ and $\mathrm{CO}_{2}$ emissions observed among yedoma and non-yedoma lakes to the extent of these lake types in Alaska (Walter Anthony et al., 2012) $\left(44 \pm 17 \mathrm{~g} \mathrm{CH}_{4} \mathrm{~m}^{-2} \mathrm{yr}^{-1} \times \sim 8800 \mathrm{~km}^{2}\right.$, yedoma lakes; $8 \pm 4 \mathrm{~g} \mathrm{CH}_{4} \mathrm{~m}^{-2} \mathrm{yr}^{-1} \times \sim 41700 \mathrm{~km}^{2}$, nonyedoma lakes), we estimate that yedoma and non-yedoma lakes emit a total of $0.72 \mathrm{Tg} \mathrm{CH}_{4} \mathrm{yr}^{-1}\left(\sim 0.39 \mathrm{Tg} \mathrm{CH}_{4} \mathrm{yr}^{-1}\right.$ from yedoma lakes, $0.33 \mathrm{Tg} \mathrm{CH}_{4} \mathrm{yr}^{-1}$ from non-yedoma lakes). This estimate of Alaskan lake emissions increases the previous estimate of Alaska's wetland ecosystem emissions (3 $\mathrm{Tg} \mathrm{CH}_{4} \mathrm{yr}^{-1}$; Zhuang et al., 2007), in which lakes were not included, by $24 \%$. Our estimate of lake $\mathrm{CH}_{4}$ emission is conservative because it does not include background (non- 
seep) ebullition or storage emissions associated with fall lake turnover events.

If we assume that our study lakes represent the $\mathrm{CH}_{4}$ and $\mathrm{CO}_{2}$ emission dynamics of all lakes in Alaska and account for the 34-fold stronger global warming potential of $\mathrm{CH}_{4}$ vs. $\mathrm{CO}_{2}$ over 100 years $\left(\mathrm{GWP}_{100}\right.$; Myhre et al., 2013), the impact on the climate based on $\mathrm{CO}_{2}$-equivalent $\left(\mathrm{CO}_{2}\right.$-eq) emissions from yedoma lakes is $\sim 20 \mathrm{Tg} \mathrm{CO}_{2}$-eq $\mathrm{yr}^{-1}(13 \mathrm{Tg}$ $\mathrm{CO}_{2}$-eq yr ${ }^{-1}$ from $\mathrm{CH}_{4}$ and $7 \mathrm{Tg} \mathrm{CO}_{2} \mathrm{yr}^{-1}$ from $\mathrm{CO}_{2}$ ). For non-yedoma lakes, the total climate impact is $\sim 17 \mathrm{Tg} \mathrm{CO}_{2}$ eq $\mathrm{yr}^{-1}\left(11 \mathrm{Tg} \mathrm{CO}_{2}\right.$-eq yr ${ }^{-1}$ from $\mathrm{CH}_{4}$ and $6 \mathrm{Tg} \mathrm{CO}_{2} \mathrm{yr}^{-1}$ from $\mathrm{CO}_{2}$ ). These results have several important implications. First, $\mathrm{CH}_{4}$ emissions have nearly twice the impact on climate as $\mathrm{CO}_{2}$ emissions among all Alaskan lakes. Second, the climate impacts of yedoma and non-yedoma lakes in Alaska due to carbon greenhouse gas emissions are approximately equal, despite yedoma lakes comprising less than one-fifth of the total lake area in Alaska. The disproportionately large climate impact of $\mathrm{CH}_{4}$ emissions from yedoma lakes is due in large part to thaw of deep, organicrich yedoma permafrost beneath these lakes; however, higher concentrations of total nitrogen, soluble reactive phosphorus, and chlorophyll $a$ in these lakes suggest enhanced primary production in the lakes, which can also fuel decomposition and methanogenesis, as recently demonstrated in Siberia (Walter Anthony et al., 2014). Based on relationships observed in Finnish lakes, it is possible that shifts in nitrate availability could also control the long-term patterns of terrestrially derived $\mathrm{CO}_{2}$ emission versus carbon sequestration by our study lakes as well.

\section{Conclusions}

Total annual $\mathrm{CH}_{4}$ and $\mathrm{CO}_{2}$ emissions were dominated by ebullition and diffusion, respectively; however, the climate warming impact of $\mathrm{CH}_{4}$ emissions was twice that of $\mathrm{CO}_{2}$. Our 40 study lakes spanned large gradients of physicochemical properties and geography in Alaska. We attribute the 6fold higher $\mathrm{CH}_{4}$ and $\mathrm{CO}_{2}$ emissions observed in thermokarst lakes formed in icy, organic-rich yedoma permafrost in interior Alaska compared to non-yedoma lakes throughout the rest of Alaska to enhanced organic matter supplied from thawing yedoma permafrost, which is typically thicker than the organic-rich strata of non-yedoma soils. Higher total nitrogen, SRP, and Chl $a$ concentrations in yedoma lakes suggest that higher primary production may also enhance organic substrate supply to decomposition and greenhouse gas production in these lakes. Consideration of multiple modes and seasonality of $\mathrm{CH}_{4}$ and $\mathrm{CO}_{2}$ emissions revealed that summer emissions were largest. However, winter and spring emissions of $\mathrm{CH}_{4}$, including direct ebullition through holes in lake ice and the ice-bubble storage and release process, were also significant components of the annual $\mathrm{CH}_{4}$ budget. Our results imply that regional assessments of lake $\mathrm{CH}_{4}$ and $\mathrm{CO}_{2}$ emissions in other parts of the pan-Arctic should take into account the myriad of emission modes and geographic characteristics, such as lake and permafrost types. 


\section{Appendix A: Methods}

\section{A1 Dissolved gas measurements}

We used the headspace equilibration tunable diode laser spectroscopy (HE-TDLAS) technique, described in detail by Sepulveda-Jauregui et al. (2012), to measure the concentration of $\mathrm{CH}_{4}$ dissolved in lake water. Briefly, we collected water samples using a Van Dorn bottle (WILDCO, Yulee, Florida, USA) and gently transferred $60 \mathrm{~mL}$ into three borosilicate vials ( $100 \mathrm{~mL}$ volume) using disposable polypropylene syringes for triplicate measurements. Vials were immediately sealed with butyl rubber stoppers and aluminum crimp caps. The vials containing the water samples were shaken vigorously for $10 \mathrm{~s}$ to transfer $\mathrm{CH}_{4}$ from the water into the vials' headspace for subsequent measurement with the GasFinder 2.0.

In addition to HE-TDLAS, we also measured dissolved $\mathrm{CH}_{4}$ and $\mathrm{CO}_{2}$ in a subset of samples using the traditional headspace equilibration method by gas chromatography (Kling et al., 1992). Water samples $(10 \mathrm{~mL})$ collected with the Van Dorn bottle were transferred into $25 \mathrm{~mL}$ glass serum bottles and immediately sealed with butyl rubber stoppers and aluminum crimp caps. Serum bottles were stored upside down and frozen until laboratory analysis. In the laboratory, we thawed the samples to room temperature, shook bottles for $10 \mathrm{~s}$ to equilibrate headspace and water samples, and then measured $\mathrm{CH}_{4}$ and $\mathrm{CO}_{2}$ of the headspace by gas chromatography (Shimadzu GC-2014).

\section{A2 Seep ebullition}

GPS-mapped ebullition seeps were classified as A, B, C, and hotspot types, based on ice-bubble morphologies. This classification system has been described in detail, with example photographs and bubble morphology classification criteria presented in multiple previous publications (Walter et al., 2006, 2008; Walter Anthony et al., 2010, 2013). Briefly, A-type ebullition seeps are relatively small clusters of ebullition bubbles in which individual bubbles stack on top of each other in the winter ice sheet without merging laterally. Due to progressively higher ebullition rates, individual bubbles of B-type seeps laterally merge into larger bubbles under the ice prior to freezing in ice. A- and B-type seeps produce low-gas-volume clusters of bubbles in lake ice with cluster diameters typically $<40 \mathrm{~cm}$. The larger C-type seeps result in large (usually $>40 \mathrm{~cm}$ diameter) pockets of gas in ice separated vertically by ice layers containing few or no bubbles. Bubble-trap measurements showed that the solid ice layers in between the large gas pockets of C-type seeps represent periods of relative quiescence in between large ebullition events (Walter et al., 2006; Walter Anthony et al., 2010). Hotspot seeps have the greatest mean daily bubbling rates. The frequency of ebullition release from hotspot seeps and the associated convection in the water column created by rising bub- ble plumes can be strong enough to maintain ice-free holes in winter lake ice or ice-free cavities covered by thin layers of ice during cold periods.

Thirty-day averages of bubbling rates $\left(\mathrm{mL}\right.$ gas seep ${ }^{-1}$ $\mathrm{d}^{-1}$ ) were determined through bubble-trap measurements of seep fluxes and associated with seep classes for each Julian day of the year (Walter Anthony et al., 2010). This data set consists of $\sim 210000$ individual flux measurements made using submerged bubble traps placed over ebullition seeps yearround. These class-specific fluxes were applied to the wholelake mean densities of seeps on lakes to derive estimates of bubble-release rates from lake bottom sediments indexed by Julian day. To determine mass-based estimates of $\mathrm{CH}_{4}$ and $\mathrm{CO}_{2}$ in ebullition bubbles, we applied lake-specific measurements of $\mathrm{CH}_{4}$ and $\mathrm{CO}_{2}$ bubble concentrations to the individual lakes where seep-bubble gases were collected and measured. Methods of bubble-trap gas collection and measurements were described in detail by Walter et al. (2008). We sampled with bubble traps and measured by gas chromatography the $\mathrm{CH}_{4}$ and $\mathrm{CO}_{2}$ compositions of seep ebullition bubbles collected from up to 246 individual ebullition events per lake. In lakes where few or no seep-bubble gas concentrations were determined, we applied mean values of $\mathrm{CH}_{4}$ and $\mathrm{CO}_{2}$ by seep class (Walter Anthony et al., 2010): A, $73 \%$ $\mathrm{CH}_{4}, 0.51 \% \mathrm{CO}_{2} ; \mathrm{B}, 75 \% \mathrm{CH}_{4}, 0.40 \% \mathrm{CO}_{2} ; \mathrm{C}, 76 \% \mathrm{CH}_{4}$, $0.55 \% \mathrm{CO}_{2}$; hotspot, $78 \% \mathrm{CH}_{4}$, and $0.84 \% \mathrm{CO}_{2}$. Wholelake mean ebullition was the sum of seep fluxes observed along an average of five $50 \mathrm{~m}$ long transects per lake (median of four transects per lake), divided by the total area surveyed. In a recent comparison of methods for quantifying ebullition, Walter Anthony and Anthony (2013) showed that when at least three $50 \mathrm{~m}$ transects per lake are used to quantify seep ebullition, the estimate of mean whole-lake ebullition is 4-5 times more accurate than the mean flux determined by placement of seventeen $0.2 \mathrm{~m}^{2}$ bubble traps randomly distributed across lake surfaces. 


\section{The Supplement related to this article is available online at doi:10.5194/bg-12-3197-2015-supplement.}

Author contributions. K. M. Walter Anthony and A. SepulvedaJauregui conceived of the study. A. Sepulveda-Jauregui and K. M. Walter Anthony wrote the manuscript. K. M. Walter Anthony, A. Sepulveda-Jauregui, K. Martinez Cruz, and F. Thalasso were responsible for field and lab work. A. Sepulveda-Jauregui conducted statistical analyses. S. Greene modeled ice-bubble storage emissions. All authors commented on the composition of the manuscript.

Acknowledgements. We thank T. Howe for lab assistance, P. Anthony for spatial analysis and maps, and A. Strohm and J. Heslop for field and lab assistance. A. Powell, C. Mulder, and the students of the 2013 Scientific Writing, Editing, and Revising in the Biological Sciences course (Biol. 604) provided valuable comments on the paper. Support for the study came from DOE DE-SC0006920, NSF OPP \#1107892, NSF ARC \#1304823, NASA \#NNX11AH20G, and the USGS NIWR. Specific support to A. Sepulveda-Jauregui and K. Martinez-Cruz came from Semarnat-Conacyt 23661, 206621/203709, and 330197/233369.

Edited by: W. F. Vincent

\section{References}

Abril, G., Guerin, F., Richard, S., Delmas, R., Galy-Lacaux, C., Gosse, P., Tremblay, A., Varfalvy, L., Dos Santos, M. A., and Matvienko, B.: Carbon dioxide and methane emissions and the carbon budget of a 10-year old tropical reservoir (Petit Saut, French Guiana), Global Biogeochem. Cy., 19, G02024, doi:10.1029/2007JG000608, 2005.

Arp, C. D. and Jones, B. M.: Geography of Alaska lake districts: Identification, description, and analysis of lake-rich regions of a diverse and dynamic state: US Geological Survey Scientific Investigations Report in: U.S.G.S.S.I., Gibbs, B., Fabian-Marks, J., Richey, B. J., Rogers, L., Richey, B. J., and Wahlstrom, S., USA, 2008-5215, 1-40, 2009.

Arp, C. D., Jones, B. M., and Grosse, G.: Recent lake ice-out phenology within and among lake districts of Alaska, USA, Limnol. and Oceanogr., 58, 2013-2028, 2013.

Bastviken, D., Ejlertsson, J., and Tranvik, L.: Measurement of Methane Oxidation in Lakes: A Comparison of Methods, Environ. Sci. Technol., 36, 3354-3361, 2002.

Bastviken, D., Cole, J., Pace, M., and Tranvik, L.: Methane emissions from lakes: Dependence of lake characteristics, two regional assessments, and a global estimate, Global Biogeochem. Cy., 18, GB4009, doi:10.1029/2004GB002238, 2004.

Bastviken, D., Cole, J. J., Pace, M. L., and Van de Bogert, M. C.: Fates of methane from different lake habitats: Connecting wholelake budgets and $\mathrm{CH}_{4}$ emissions, J. Geophys. Res.-Biogeosci., 113, G02024, doi:10.1029/2007JG000608, 2008.
Bastviken, D., Tranvik, L. J., Downing, J. A., Crill, P. M., and Enrich-Prast, A.: Freshwater Methane Emissions Offset the Continental Carbon Sink, Science, p. 331, 2011.

Battin, T. J., Luyssaert, S., Kaplan, L. A., Aufdenkampe, A. K., Richter, A., and Tranvik, L. J.: The boundless carbon cycle, Nat. Geosci., 2, 598-600, 2009.

Bellido, J. L., Tulonen, T., Kankaala, P., and Ojala, A.: $\mathrm{CO}_{2}$ and $\mathrm{CH}_{4}$ fluxes during spring and autumn mixing periods in a boreal lake (Paajarvi, southern Finland), J. Geophys. Res.-Biogeosci., 114, G04007, doi:10.1029/2009JG000923, 2009.

Boereboom, T., Depoorter, M., Coppens, S., and Tison, J.-L.: Gas properties of winter lake ice in Northern Sweden: implication for carbon gas release, Biogeosciences, 9, 827-838, doi:10.5194/bg9-827-2012, 2012.

Borrel, G., Jezequel, D., Biderre-Petit, C., Morel-Desrosiers, N., Morel, J. P., Peyret, P., Fonty, G., and Lehours, A. C.: Production and consumption of methane in freshwater lake ecosystems, Res. Microbiol., 162, 832-847, 2011.

Brosius, L. S., Walter Anthony, K. M., Grosse, G., Chanton, J. P., Farquharson, L. M., Overduin, P. P., and Meyer, H.: Using the deuterium isotope composition of permafrost meltwater to constrain thermokarst lake contributions to atmospheric $\mathrm{CH}_{4}$ during the last deglaciation, J. Geophys. Res.-Biogeosci.,117, G01022, doi:10.1029/2011JG001810, 2012.

Camacho, A.: On the occurrence and ecological features of deep chlorophyll maxima (DCM) in Spanish stratified lakes, Limentica, 25, 453-478, 2006.

Carlson, R. E.: Trophic State Index For Lakes, Limnol. Oceanogr., 22, 361-369, 1977.

Carlson, R. E. and Simpson, J.: A Coordinator's Guide to Volunteer Lake Monitoring Methods, North American Lake Management Society, 96 pp., 1996.

Casper, P., Maberly, S. C., Hall, G. H., and Finlay, B. J.: Fluxes of methane and carbon dioxide from a small productive lake to the atmosphere, Biogeochemistry, 49, 1-19, 2000.

Clilverd, H., White, D., and Lilly, M.: Chemical and physical controls on the oxygen regime of ice-covered arctic lakes and reservoirs, J. Am. Water Resour. As., 45, 500-511, 2009

Cole, J. J. and Caraco, N. F.: Atmospheric exchange of carbon dioxide in a low-wind oligotrophic lake measured by the addition of SF, Limnol. Oceanogr., 43, 647-656, 1998.

Cole, J. J., Prairie, Y. T., Caraco, N. F., McDowell, W. H., Tranvik, L. J., Striegl, R. G., Duarte, C. M., Kortelainen, P., Downing, J. A., Middelburg, J. J., and Melack, J.: Plumbing the global carbon cycle: Integrating inland waters into the terrestrial carbon budget, Ecosystems, 10, 171-184, 2007.

Conrad, R., Claus, P., and Casper, P.: Stable isotope fractionation during the methanogenic degradation of organic matter in the sediment of an acidic bog lake, Lake Grosse Fuchskuhle, Limnol. Oceanogr., 55, 1932-1942, 2010.

Dean, W. E.: Determination of carbonate and organic matter in calcareous sediments and sedimentary rocks by loss on ignition; comparison with other methods, J. Sediment Res., 44, 242-248, 1974.

Del Giorgio, P., Cole, J. J., Caraco, N. F., and Peters, R. H.: Linking planktonic biomass and metabolism to net gas fluxes in northern temperate lakes, Ecology, 80, 1422-1431, 1999.

Downing, J. A., Prairie, Y. T., Cole, J. J., Duarte, C. M., Tranvik, L. J., Striegl, R. G., McDowell, W. H., Kortelainen, P., Caraco, 
N. F., Melack, J. M., and Middelburg, J. J.: The global abundance and size distribution of lakes, ponds, and impoundments, Limnol. Oceanogr., 51, 2388-2397, 2006.

Duc, N. T., Crill, P., and Bastviken, D.: Implications of temperature and sediment characteristics on methane formation and oxidation in lake sediments, Biogeochemistry, 100, 185-196, 2010.

Dunfield, P., Knowles, R., Dumont, R., and Moore, T. R.: Methane production and consumption in temperate and sub-arctic peat soils-response to temperature and $\mathrm{pH}$, Soil Biol. Biochem., 25, 321-326, 1993.

Dzyuban, A. N.: Dynamics of microbial oxidation of methane in the water of stratified lakes, Microbiology, 79, 822-829, 2010.

Gervais, F., Padisak, J., and Koschel, R.: Do light quality and low nutrient concentration favour picocyanobacteria below the thermocline of the oligotrophic Lake Stechlin?, J. Plankton Res., 19, 771-781, 1997.

Giblin, A., Luecke, C., Kling, G., and White, D.: Nutrient and chemical data for various lakes near Toolik Research Station, Arctic LTER, Summer 2009, Long Term Ecological Research Network, doi:10.6073/pasta/1b77f4c8d8cc250ce0f90bbb17d9c976, 2009.

Gow, A. J. and Langston, D.: Growth history of lake ice in relation to its stratigraphic, crystalline and mechanical structure, US Army, Corps of Engineers, Cold Regions Research and Engineering Laboratory, Hanover, New Hampshire, 24 pp., 1977.

Graneli, W., Lindell, M., and Tranvik, L.: Photo-oxidative production of dissolved inorganic carbon in lakes of different humic content, Limnol. Oceanogr., 41, 698-706, 1996.

Greene, S., Walter Anthony, K. M., Archer, D., Sepulveda-Jauregui, A., and Martinez-Cruz, K.: Modeling the impediment of methane ebullition bubbles by seasonal lake ice, Biogeosciences, 11, 6791-6811, doi:10.5194/bg-11-6791-2014, 2014.

Gregory-Eaves, I., Smol, J. P., Finney, B. P., Lean, D. R. S., and Edwards, M. E.: Characteristics and variation in lakes along a north-south transect in Alaska, Arch. Hydrobiol., 147, 193-223, 2000.

Grosse, G., Jones, B., and Arp., C.: Thermokarst lakes, drainage, and drained basins, Treatise Geomorph., 8, 325-353, 2013.

Guerin, F. and Abril, G.: Significance of pelagic aerobic methane oxidation in the methane and carbon budget of a tropical reservoir, J. Geophys. Res.-Biogeosci., 112, G03006, doi:10.1029/2006JG000393, 2007.

Haberman, J. and Haldna, M.: Indices of zooplankton community as valuable tools in assessing the trophic state and water quality of eutrophic lakes: long term study of Lake Vortsjarv, J. Limnol., 73, 263-273, 2014.

Jorgenson, T., Yoshikawa, K., Kanevskiy, M., Shur, Y., Romanovsky, V., Marchenko, S., Grosse, G., Brown, J., and Jones, B.: Permafrost Characteristics of Alaska, Institute of Northern Engineering, University of Alaska Fairbanks NICOP, University of Alaska Fairbanks, USA, 2008.

Juutinen, S., Rantakari, M., Kortelainen, P., Huttunen, J. T., Larmola, T., Alm, J., Silvola, J., and Martikainen, P. J.: Methane dynamics in different boreal lake types, Biogeosciences, 6, 209223, doi:10.5194/bg-6-209-2009, 2009.

Kanevskiy, M., Shur, Y., Fortier, D., Jorgenson, M. T., and Stephani, E.: Cryostratigraphy of late Pleistocene syngenetic permafrost (yedoma) in northern Alaska, Itkillik River exposure, Quaternary Res., 75, 584-596, 2011.

Kankaala, P., Huotari, J., Peltomaa, E., Saloranta, T., and Ojala, A.: Methanotrophic activity in relation to methane efflux and total heterotrophic bacterial production in a stratified, humic, boreal lake, Limnol. Oceanogr., 51, 1195-1204, 2006.

Karlstrom, T. W., Coulter, H. W., Fernald, A. T., Williams, J. R., Hopkins, D. M., Pewe, T. L., Drewes, H., Muller, E. H., and Condon, W. H.: Surficial Geology of Alaska, U.S. Geological Survey Map, IMAP-357, http://pubs.er.usgs.gov/publication/i357, Interior, U.S.D.O., Alaska, USA, 1964.

Kessler, M. A., Plug, L., and Walter Anthony, K. M.: Simulating the decadal to millennial scale dynamics of morphology and sequestered carbon mobilization of two thermokarst lakes in N. W. Alaska, J. Geophys. Res., 117, G00M06, doi:10.1029/2011JG001796, 2012.

Kling, G. W.: Field and lab methods and protocols, Protocol version: v2.8, Kling Lab University of Michigan, 2010.

Kling, G. W., Kipphut, G. W., and Miller, M. C.: Arctic lakes and streams as gas conduits to the atmosphere - implications for tundra carbon budgets, Science, 251, 298-301, 1991.

Kling, G. W., Kipphut, G. W., and Miller, M. C.: The flux of $\mathrm{CO}_{2}$ and $\mathrm{CH}_{4}$ from lakes and rivers in arctic Alaska, Hydrobiologia, 240, 23-36, 1992.

Kortelainen, P., Rantakari, M., Huttunen, J. T., Mattsson, T., Alm, J., Juutinen, S., Larmola, T., Silvola, J., and Martikainen, P. J.: Sediment respiration and lake trophic state are important predictors of large $\mathrm{CO}_{2}$ evasion from small boreal lakes, Glob. Change Biol., 12, 1554-1567, 2006.

Kortelainen, P., Rantakari, M., Pajunen, H., Mattsson, T., Juutinen, S., Larmola, T., Alm, J., Silvola, J., and Martikainen, P. J.: Carbon evasion/accumulation in boreal lakes is linked to nitrogen, Global Biogechem. Cy., 27, 363-374, 2013.

Langer, M., Westermann, S., Walter Anthony, K., Wischnewski, K., and Boike, J.: Frozen ponds: production and storage of methane during the Arctic winter in a lowland tundra landscape in northern Siberia, Lena River delta, Biogeosciences, 12, 977-990, doi:10.5194/bg-12-977-2015, 2015.

Lapierre, J. F. and Del Giorgio, P. A.: Geographical and environmental drivers of regional differences in the lake $p \mathrm{CO}_{2}$ vs. DOC relationship across northern landscapes, J. Geophys. Res., 117, G03015, doi:10.1029/2012JG001945, 2012.

Lofton, D. D., Whalen, S. C., and Hershey, A. E.: Effect of temperature on methane dynamics and evaluation of methane oxidation kinetics in shallow Arctic Alaskan lakes, Hydrobiologia, 721, 209-222, 2014.

Maberly, S. C., Barker, P. A., Stott, A. W., and De Ville, M. M.: Catchment productivity controls $\mathrm{CO}_{2}$ emissions from lakes, Nat Clim. Change, 3, 391-394, 2013.

Madigan, M. T., Martinko, J. M., Dunlap, P. V., and Clark, D. P.: Brock biology of microorganisms, 12th Edn. Pearson education, 2009.

Marotta, H., Pinho L., Bastviken D., Tranvik L. J., and Enrich-Prast A.: Greenhouse gas production in low-latitude lake sediments responds strongly to warming, Nat. Clim. Change, 4, 467-470, 2014.

Martens, C. S., Kelley, C. A., Chanton, J. P., and Showers, W. J.: Carbon and hydrogen isotopic characterization of methane from 
wetlands and lakes of the Yukon-Kuskokwim Delta, Western Alaska, J. Geophys. Res.-Atmos., 97, 16689-16701, 1992.

Martinez-Cruz, K., Sepulveda-Jauregui, A., Walter Anthony, K. M., and Thalasso, F.: Latitudinal and seasonal variation of aerobic methane oxidation in Alaskan lakes, Biogeosciences Discuss., in press, 2015.

Michmerhuizen, C. M., Striegl, R. G., and McDonald, M. E.: Potential methane emission from north-temperate lakes following ice melt, Limnol. Oceanogr., 41, 985-991, 1996.

Myhre, G., Shindell, D., Breon, F. M., Collins, W., Fuglestvedt, J., Huang, J., Koch, D., Lamarque, J. F., Lee, D., Mendoza, B., Nakajima, T., Robock, A., Stephens, G., Takemura, T., and Zhang, H.: Anthropogenic and Natural Radiative Forcing, in: Climate Change 2013: The Physical Science Basis, Contribution of Working Group I to the Fifth Assessment Report of the Intergovernmental Panel on Climate Change, Cambridge University Press, Cambridge, United Kingdom and New York, NY, USA, 2013.

National Institute of Standards and Technology (NIST): NIST chemistry Web book, 2011.

Ohman, J., Buffam, I., Englund, G., Blom, A., Lindgren, E., and Laudon L.: Associations between water chemistry and fish community composition: a comparison between isolated and connected lakes in northern Sweden, Freshwater Biol., 51, 510-522, 2006.

Ortiz-Llorente, M. J. and Alvarez-Cobelas, M.: Comparison of biogenic methane emissions from unmanaged estuaries, lakes, oceans, rivers and wetlands, Atmos. Environ., 59, 328-337, 2012.

Phelps, A. R., Peterson, K. M., and Jeffries, M. O.: Methane efflux from high-latitude lakes during spring ice melt, J. Geophys. Res.Atmos., 103, 29029-29036, 1998.

Ping, C. L., Michaelson, G. J., Jorgenson, M. T., Kimble, J. M., Epstein, H., Romanovsky, V. E., and Walker, D. A.: High stocks of soil organic carbon in the North American Arctic region, Nat. Geosci., 1, 615-619, 2008.

Rasilo, T., Prairie, Y. T., and Del Giorgio, P. A.: Large-scale patterns in summer diffusive $\mathrm{CH}_{4}$ fluxes across boreal lakes, and contribution to diffusive $\mathrm{C}$ emissions, Glob. Change Biol., 21, 1124-1139, 2015.

Repo, M. E., Huttunen, J. T., Naumov, A. V., Chichulin, A. V., Lapshina, E. D., Bleuten, W., and Martinkainen, P. J.: Release of $\mathrm{CO}_{2}$ and $\mathrm{CH}_{4}$ from small wetland lakes in western Siberia, Tellus B, 59, 788-796, 2007.

Schulz, S., Matsuyama, H., and Conrad, R.: Temperature dependence of methane production from different precursors in a profundal sediment (Lake Constance), Fems Microb. Ecol., 22, 207213, 1997.

Semiletov, I. P., Pipko, II, Pivovarov, N. Y., Popov, V. V., Zimov, S. A., Voropaev, Y. V., and Daviodov, S. P.: Atmospheric carbon emission from North Asian Lakes: A factor of global significance, Atmos. Environ., 30, 1657-1671, 1996.

Sepulveda-Jauregui, A., Martinez-Cruz, K., Strohm, A., Walter Anthony, K. M., and Thalasso, F.: A new method for field measurement of dissolved methane in water using infrared tunable diode laser absorption spectroscopy, Limnol. Oceanogr.-Meth., 10, 560-567, 2012.

Smith, L. C., Sheng, Y. W., and MacDonald, G. M.: A first panArctic assessment of the influence of glaciation, permafrost, to- pography and peatlands on northern hemisphere lake distribution, Permafrost Periglac., 18, 201-208, 2007.

Tan, Z., Zhuang, Q., and Walter Anthony, K. M.: Modeling methane emissions from arctic lakes: model development and site-level study, J. Adv. Model. Earth Sy., 7, doi:10.1002/2014MS000344, 2015.

Tarnocai, C., Canadell, J.G., Schuur, E.A.G., Kuhry, P., Mazhitova, G., and Zimov, S.: Soil organic carbon pools in the northern circumpolar permafrost region, Global Biogeochem. Cy., 23, GB2023, doi:10.1029/2008GB003327, 2009.

Tedford, E. W., MacIntyre1, S., Miller, S. D., and Czikowsky, M. J.: Similarity scaling of turbulence in a temperate lake during fall cooling, J. Geophys. Re.-Oceans, 119, 4689-4713, 2014.

Tranvik, L. J., Downing, J. A., Cotner, J. B., Loiselle, S. A., Striegl, R. G., Ballatore, T. J., Dillon, P., Finlay, K., Fortino, K., Knoll, L. B., Kortelainen, P. L., Kutser, T., Larsen, S., Laurion, I., Leech, D. M., McCallister, S. L., McKnight, D. M., Melack, J. M., Overholt, E., Porter, J. A., Prairie, Y., Renwick, W. H., Roland, F., Sherman, B. S., Schindler, D. W., Sobek, S., Tremblay, A., Vanni, M. J., Verschoor, A. M., von Wachenfeldt, E., and Weyhenmeyer, G. A.: Lakes and reservoirs as regulators of carbon cycling and climate, Limnol. Oceanogr., 54, 2298-2314, 2009.

Utsumi, M., Nojiri, Y., Nakamura, T., Nozawa, T., Otsuki, A., Takamura, N., Watanabe, M., and Seki, H.: Dynamics of dissolved methane and methane oxidation in dimictic Lake Nojiri during winter, Limnol. Oceanogr., 43, 10-17, 1998.

Vonk, J. E., Mann, P. J., Davydov, S., Davydova, A., Spencer, R. G. M., Schade, J., Sobzak, W. V., Zimov, N., Zimov, S., Bulygina, E., Eglington, T. I., and Holmes, R. M. High biolability of ancient permafrost carbon upon thaw, J. Geophys. Res. Lett., 40, 26892693, 2013.

Walter, K. M., Zimov, S. A., Chanton, J. P., Verbyla, D., and Chapin, F. S.: Methane bubbling from Siberian thaw lakes as a positive feedback to climate warming, Nature, 443, 71-75, 2006.

Walter, K. M., Engram, M., Duguay, C. R., Jeffries, M. O., and Chapin, F. S.: The potential use of synthetic aperture radar for estimating methane ebullition from Arctic lake, J. Am. Water Resour. As., 44, 305-315, 2008.

Walter Anthony, K. M., Vas, D. A., Brosius, L., Chapin, F. S., Zimov, S. A., and Zhuang, Q. L.: Estimating methane emissions from northern lakes using ice-bubble surveys, Limnol. Oceanogr.-Meth., 8, 592-609, 2010.

Walter Anthony, K. M., Anthony, P., Grosse, G., and Chanton, J.: Geologic methane seeps along boundaries of Arctic permafrost thaw and melting glaciers, Nat. Geosci., 5, 419-426, 2012.

Walter Anthony, K. M. and Anthony, P.: Constraining spatial variability of methane ebullition seeps in thermokarst lakes using point process models, J. Geophys. Res.-Biogeosci., 118, 10151034, 2013.

Walter Anthony, K. M., Zimov S. A., Grosse, G., Jones, M. C., Anthony, P., Chapin III, F. S., Finlay, J. C., Mack, M. C., Davydov, S., Frenzel, P., and Frolking S.: A shift of thermokarst lakes from carbon sources to sinks during the Holocene epoch, Nature, 511, 452-456, 2014.

Welch, H. E., Legault, J. A., and Bergmann, M. A.: Effects of snow and ice on the annual cycles of heat and light in Saqvaqjuac Lakes, Can. J. Fish. Aquat. Sci., 44, 1451-1461, 1987. 
Weyhenmeyer G. A. and Karlsson, J.: Nonlinear response of dissolved organic carbon concentrations in boreal lakes to increasing temperatures, Limnol. Oceanogr., 54, 2513-2519, 2009.

Weyhenmeyer, G. A., Kortelainen, P, Sobek, S., Muller, R., and Rantakari, M.: Carbon Dioxide in Boreal Surface Waters: A Comparison of Lakes and Streams, Ecosystems, 15, 1295-1307, 2012.

West, J. J. and Plug, L. J.: Time-dependent morphology of thaw lakes and taliks in deep and shallow ground ice, J. Geophys. Res.Earth Surf., 113, F01009, doi:10.1029/2006JF000696, 2008.

Wetzel, R. G.: Limnology: Lake and River Ecosystems. Academic Press Elsevier, San Diego, California, USA, 2001.

White, D. M., Clilverd, H. M., Tidwell, A. C., Little, L., Lilly, M. R., Chambers, M., and Reichardt, D.: A tool for modeling the winter oxygen depletion rate in arctic lakes, J. Am. Water Resour. As., 44, 293-304, 2008.

Williamson, C. E., Morris, D. P., Pace, M. L., and Olson, O. G.: Dissolved organic carbon and nutrients as regulators of lake ecosystems: Resurrection of a more integrated paradigm, Limnol. Oceanogr., 44, 795-803, 1999.

Yvon-Durocher, G., Allen, A. P., Bastviken, D., Conrad, R., Gudasz, C., St-Pierre, A., Thanh-Duc, N., and Del Giorgio, P. A.: Methane fluxes show consistent temperature dependence across microbial to ecosystem scales, Nature, 507, 488-491, 2014.
Zhuang, Q., Melillo, J. M., McGuire, A. D., Kicklighter, D. W., Prinn, R. G., Steudler, P. A., Felzer, B. S., and Hu, S.: Net emissions of $\mathrm{CH}_{4}$ and $\mathrm{CO}_{2}$ in Alaska: Implications for the region's greenhouse gas budget, Ecol. Appl., 17, 203-212, 2007.

Zimov, S. A., Voropaev, Y. V., Semiletov, I. P., Davidov, S. P., Prosiannikov, S. F., Chapin, F. S., Chapin, M. C., Trumbore, S., and Tyler, S.: North Siberian lakes: A methane source fueled by Pleistocene carbon, Science, 277, 800-802, 1997.

Zimov, S. A., Voropaev, Y. V., Davydov, S. P., Zimova, G. M., Davydova, A. I., Chapin III, F. S., and Chapin, M. C.: Flux of methane from north Siberian aquatic systems: Influence on atmospheric methane, in: Permafrost Response on Economic Development, Environmental Security and Natural Resources, NATO Science Series 2, 76, edited by: Paepe, R. and Melnikov, V. P., Kluwer Academic Publishers, Dordrecht, Netherlands; Boston, Massachusetts, USA, 511-524, 2001.

Zimov, S. A., Schuur, E. A. G., and Chapin III, F. S.: Permafrost and the Global Carbon Budget, Science, 312, 1612-1613, 2006. 